\title{
Dissolved-Solids Contribution to the Colorado River from Public Lands in Southeastern Nevada, Through September 1993
}

By Craig L. Westenburg

U.S. GEOLOGICAL SURVEY

Water-Resources Investigations Report 94-4210

Prepared in cooperation with the

BUREAU OF LAND MANAGEMENT

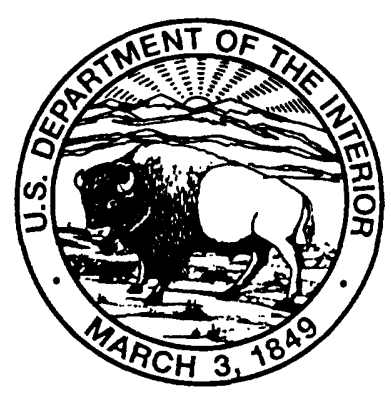

Carson City, Nevada 1995 


\title{
U.S. DEPARTMENT OF THE INTERIOR BRUCE BABBITT, Secretary
}

\author{
U.S. GEOLOGICAL SURVEY \\ Gordon P. Eaton, Director
}

Any use of trade names in this publication is for descriptive purposes

only and does not constitute endorsement by the U.S. Government.

For additional information write to:

District Chief

U.S. Geological Survey

333 West Nye Lane, Room 203

Carson City, NV 89706-0866
Copies of this report can be purchased from:

U.S. Geological Survey Earth Science Information Center Open-File Reports Section Box 25286, MS 517 Denver Federal Center Denver, CO 80225-0046 


\section{CONTENTS}

Abstract

Introduction

Purpose and Scope.

Description of Study Area and Study Sites

Methods Used to Estimate Dissolved-Solids Concentration, Load, and Yield ................................................. 12

Estimated Dissolved-Solids Concentration, Yield, and Load ............................................................................... 15

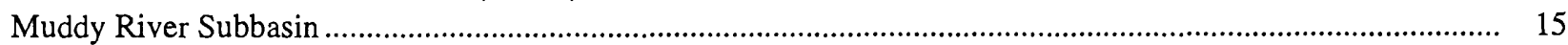

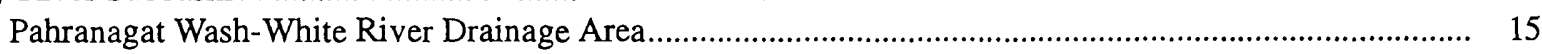

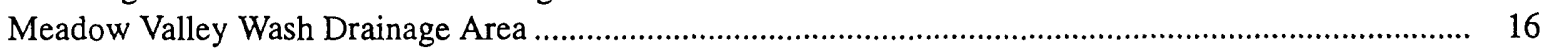

Lower Muddy River Drainage Area .............................................................................................. 16

Estimated Annual Dissolved-Solids Discharge to the Colorado River....................................................... 16

Comparison of Study-Period and Long-Term Data ........................................................................ 18

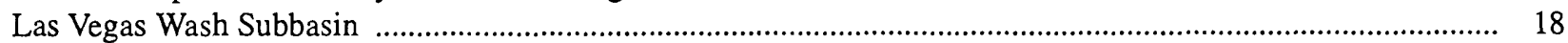

Estimated Annual Dissolved-Solids Discharge to the Colorado River....................................................... 19

Comparison of Study-Period and Long-Term Data ......................................................................... 19

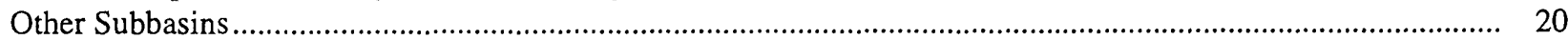

Estimated Annual Dissolved-Solids Discharge to the Colorado River.................................................... 20

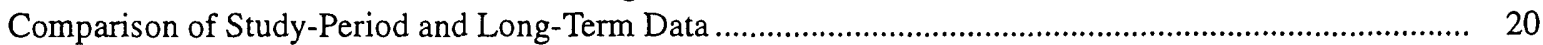

Estimated Annual Dissolved-Solids Yield and Load from Public Lands ................................................................. 21

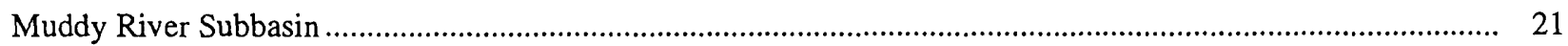

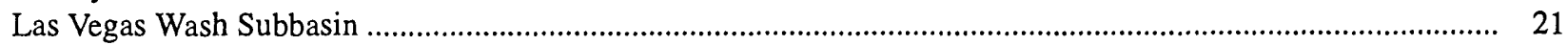

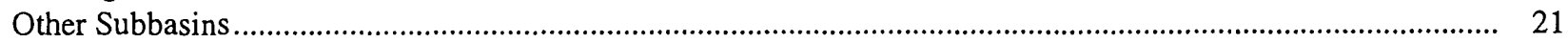

Implication of Findings for Management of Dissolved-Solids Discharge from Public Lands........................................ 22

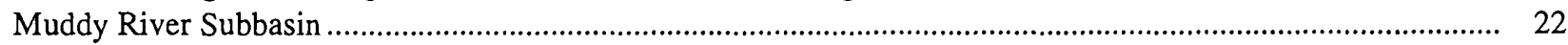

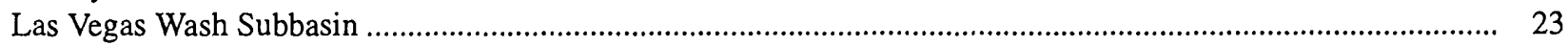

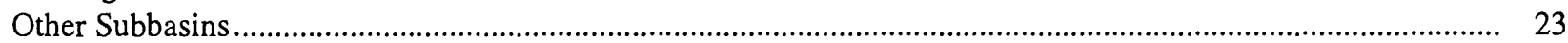

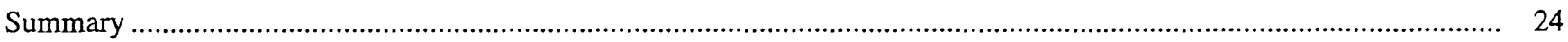

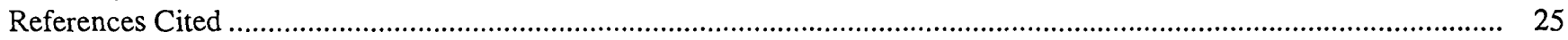

\section{FIGURES}

1. Map showing location of public lands, drainage areas, study sites, and streams tributary

to Colorado River in southeastern Nevada.

2-3. Graphs showing average streamflow for $1989-93$ at study sites in:

2. Muddy River subbasin...

3. Las Vegas Wash subbasin.

4-6. Graphs showing:

4. Annual average streamflow at four study sites with long-term record..

5. Relation between specific conductance and dissolved-solids concentration for water samples collected at study sites

6. Annual average dissolved-solids load at four study sites, 1989-93

\section{TABLES}

1. Area of subbasins in study area, of subbasins upstream from study sites, and of public lands within subbasins

2. Annual average streamflow, specific conductance, dissolved-solids concentration, and dissolved-solids load at selected study sites.

3. Data on drainage area, streamflow, and dissolved solids at study sites.

4. Summary of average annual dissolved-solids yield, load, and discharge for drainage areas and subbasins. 


\section{CONVERSION FACTORS AND ABBREVIATED WATER-QUALITY UNITS}

\begin{tabular}{rll}
\hline Multiply & By & To obtaln \\
\hline acre & 4,047 & square meter \\
acre-foot $(\mathrm{acre}-\mathrm{ft})$ & 1,233 & cubic meter \\
cubic meter per year \\
acre-foot per year (acre- $\mathrm{ft} / \mathrm{yr})$ & 1,233 & cubic meter per second \\
cubic foot per second $\left(\mathrm{ft}^{3} / \mathrm{s}\right)$ & 0.02832 & kilometer \\
$\mathrm{mile}^{(\mathrm{mi})}$ & 1.609 & square kilometer \\
square $\mathrm{mile}\left(\mathrm{mi}^{2}\right)$ & 2.590 & tonne \\
ton & 0.9072 & tonne per square kilometer \\
tonne per year
\end{tabular}

Temperature: Degrees Celsius $\left({ }^{\circ} \mathrm{C}\right)$ can be converted to degrees Fahrenheit $\left({ }^{\circ} \mathrm{F}\right)$ by using the formula ${ }^{\circ} \mathrm{F}=\left[1.8\left({ }^{\circ} \mathrm{C}\right)\right]+32$.

Water-quality units used in this report:

$\mathrm{mg} / \mathrm{L} \quad$ milligram per liter

$\mu \mathrm{S} / \mathrm{cm} \quad$ microsiemens per centimeter at 25 degrees Celsius 


\title{
Dissolved-Solids Contribution to the Colorado River from Public Lands in Southeastern Nevada, Through September 1993
}

\author{
By Craig L. Westenburg
}

\section{ABSTRACT}

The Bureau of Land Management administers about 9,300 square miles of public lands in southeastern Nevada that are part of the Colorado River Basin. About 6,200 square miles of public lands are in the Muddy River subbasin in Nevada. The estimated average dissolved-solids load contributed to the Colorado River from those lands was 28,000 tons per year from October 1988 through September 1993. Subsurface flow contributed about 86 percent $(24,000$ tons per year) of that load.

About 730 square miles of public lands in the Las Vegas Wash subbasin contribute dissolved-solids load to the Colorado River. (About 120 square miles of public lands do not contribute to the river.) The estimated average dissolved-solids load contributed to the river from those lands was about 1,300 tons per year from October 1988 through September 1993. Subsurface flow contributed almost all of that load.

About 1,100 square miles of public lands are in the Virgin River subbasin in Nevada. The estimated average dissolved-solids load contributed to the Colorado River from Nevada public lands in the subbasin was 8,700 tons per year. Subsurface flow contributed almost the entire load.

About 1,200 square miles of Nevada public lands are in ephemeral tributaries that drain directly to the Colorado River or its impoundments (Lake Mead and Lake Mohave). The estimated average dissolved-solids load contributed to the river from those lands was 50 tons per year from surface runoff; however, the dissolved-solids load contributed by subsurface flow was not estimated.
From October 1992 through September 1993, the Colorado River carried about $6,600,000$ tons of dissolved solids past a streamflow gaging station 0.3 mile downstream from Hoover Dam. In contrast, surface runoff and subsurface flow contribute an estimated average dissolved-solids load of 38,000 tons per year from public lands in southeastern Nevada to the Colorado River. Landmanagement practices probably would not substantially reduce this contribution.

\section{INTRODUCTION}

The Colorado River provides municipal and industrial water for more than 18 million people in seven states and irrigation water to more than 1.7 million acres of land (U.S. Department of the Interior, 1991, p. S-1). The dissolved-solids load (salt load) of the Colorado River is a concern in the United States and the Republic of Mexico. For example, from October 1992 through September 1993, the Colorado River carried about $6,600,000$ tons of dissolved solids in about 7,000,000 acre-ft of water (average dissolvedsolids concentration of $690 \mathrm{mg} / \mathrm{L}$ and average streamflow of $9,700 \mathrm{ft}^{3} / \mathrm{s}$ ) past a streamflow gaging station 0.3 mi downstream from Hoover Dam (U.S. Geological Survey, 1994, p. 94-95).

Public Laws 93-320 and 98-569 authorize the Secretaries of the Department of the Interior and the Department of Agriculture to enhance and protect the quality of water in the Colorado River for use in the United States and the Republic of Mexico (U.S. Department of the Interior, 1991, p. S-1). Public Law 98-569 directs the Secretary of the Interior to develop a comprehensive program for minimizing dissolvedsolids contributions to the Colorado River from lands administered by the Bureau of Land Management (U.S. Department of the Interior, 1991, p. S-1 and 52). 
The Bureau of Land Management (BLM) administers about 75 percent (table 1) of lands in the Nevada part of the Colorado River Basin. Lands administered by BLM are herein referred to as public lands. In the Colorado River Basin of southeastern Nevada, about $6,200 \mathrm{mi}^{2}$ of public lands are in the Muddy River subbasin, about $850 \mathrm{mi}^{2}$ are in the Las Vegas Wash subbasin, about $1,100 \mathrm{mi}^{2}$ are in the Virgin River subbasin, and about $1,200 \mathrm{mi}^{2}$ are drained by ephemeral tributaries to the Colorado River (table 1).

Municipal, industrial, and agricultural water uses downstream from public lands in the Muddy River and Las Vegas Wash subbasins are potential sources of dissolved-solids load. Data available prior to 1988 for the two subbasins were generally for locations downstream from all potential sources of dissolved solids and were insufficient to estimate dissolved-solids contributions from public lands only.

The U.S. Geological Survey (USGS), in cooperation with BLM, began a 5-year program in October 1988 to assess the contribution of dissolved solids from public lands in the Colorado River Basin of southeastern Nevada. Four study sites were established in calendar year 1988 as part of this study-one each on Pahranagat Wash, Muddy River, Meadow Valley Wash, and Las Vegas Wash (fig. 1) - and data were collected through September 1993. Selected data collected at these sites through September 1991 are listed by Gortsema (1993). The streamflow, specific-conductance, and dissolved-solids data collected from October 1988 to September 1993 are in annual reports by the U.S. Geological Survey (1990-94). In addition to data from these four sites, data from other sites were used in the assessment.

The data are reported herein by water year, which is the 12-month period from October 1 to September 30, designated by the calendar year in which it ends.

\section{Purpose and Scope}

The purpose of this report is to present an assessment of dissolved solids contributed from Nevada public lands drained by the Muddy River, Las Vegas Wash, Virgin River, and ephemeral tributaries, and the consequent dissolved-solids discharge to the Colorado River and its impoundments (Lake Mead and Lake Mohave).
The average annual dissolved-solids load from these subbasins and the average annual dissolved-solids load contributed from public lands in the subbasins are summarized.

The annual dissolved-solids discharge to the Colorado River for the study period (water years 198993) is compared with available long-term data to determine whether the assessment can be extended over a longer period. The surface runoff and subsurface flow components of the annual dissolved-solids contributions are discussed.

With adequate environmental information, sources of dissolved solids probably could be identified, and the need for salinity control in future land-use planning evaluated. The identification of specific sources of dissolved solids was not within the scope of this report. Sufficient data were collected, however, to provide a basis for more detailed identification of sources of dissolved solids on public lands if further evaluation becomes necessary.

\section{Description of Study Area and Study Sites}

The area of study discussed herein includes the following subbasins of the Colorado River Basin in Nevada: the entire Las Vegas Wash subbasin and the Nevada parts of the Muddy River subbasin, the Virgin River subbasin, and the ephemeral tributaries that drain to the river and its impoundments (fig. 1).

The Muddy River subbasin, which is drained by the Muddy River, is divided into three drainage areas: Pahranagat Wash-White River, Meadow Valley Wash, and lower Muddy River (table 1, fig. 1). Three sites established as part of this study (Pahranagat Wash near Moapa, Muddy River near Moapa, and Meadow Valley Wash near Rox) in addition to the site on the Muddy River above Lake Mead near Overton constitute the study sites in the Muddy River subbasin (fig. 1). The Pahranagat Wash-White River drainage area consists of the White River, Pahranagat Wash, and their ephemeral tributaries within the drainage area. The Meadow Valley Wash drainage area consists of Meadow Valley Wash and its ephemeral tributaries upstream from the confluence with Muddy River. The lower Muddy River drainage area consists of the Muddy River and its ephemeral tributaries downstream from Pahranagat Wash and Meadow Valley Wash. 
Table 1. Area of subbasins in study area, of subbasins upstream from study sites, and of public lands within subbasins [Symbol: --, not applicable for specific designation]

\begin{tabular}{|c|c|c|c|c|c|}
\hline \multicolumn{2}{|c|}{ Subbasins and hydrographic areas in Nevada (HA) ${ }^{1}$} & \multicolumn{2}{|c|}{$\begin{array}{l}\text { Entire subbasin upstream } \\
\text { from study site }\end{array}$} & \multicolumn{2}{|c|}{$\begin{array}{l}\text { Public lands in Nevada part of } \\
\text { subbasin }\end{array}$} \\
\hline Designation & $\begin{array}{l}\text { Total area } \\
\text { (square } \\
\text { miles) }\end{array}$ & $\begin{array}{l}\text { Area } \\
\text { (square } \\
\text { miles) }\end{array}$ & $\begin{array}{l}\text { Percentage of } \\
\text { total area }\end{array}$ & $\begin{array}{l}\text { Area }^{2} \\
\text { (square } \\
\text { miles) }\end{array}$ & $\begin{array}{l}\text { Percentage of } \\
\text { total area }\end{array}$ \\
\hline Nevada part of Colorado River Basin & 12,371 & -- & -- & 9,300 & 75 \\
\hline Muddy River subbasin & ${ }^{3} 7,225$ & 47,230 & 100 & 6,200 & 86 \\
\hline Pahranagat Wash-White River drainage area & 3,865 & $5_{3,830}$ & 99 & 3,200 & 83 \\
\hline $\begin{array}{l}\text { Kane Springs Valley (HA 206) } \\
\text { White River Valley (HA 207) } \\
\text { Pahroc Valley (HA 208) }\end{array}$ & $\begin{array}{r}234 \\
1,607 \\
508\end{array}$ & & & & \\
\hline $\begin{array}{l}\text { Pahranagat Valley (HA 209) } \\
\text { Coyote Spring Valley (HA 210) } \\
\text { Muddy River Springs area (HA 219) }\end{array}$ & $\begin{array}{r}768 \\
657 \\
91\end{array}$ & & & & \\
\hline Meadow Valley Wash drainage area & ${ }^{3} 2,559$ & ${ }^{6} 2,384$ & 93 & 2,400 & 94 \\
\hline $\begin{array}{l}\text { Dry Valley (HA 198) } \\
\text { Rose Valley (HA 199) } \\
\text { Eagle Valley (HA 200) } \\
\text { Spring Valley (HA 201) }\end{array}$ & $\begin{array}{r}3113 \\
12 \\
52 \\
{ }^{3} 287\end{array}$ & & & & \\
\hline $\begin{array}{l}\text { Patterson Valley (HA 202) } \\
\text { Panaca Valley (HA 203) } \\
\text { Clover Valley (HA 204) } \\
\text { Lower Meadow Valley Wash (HA 205) }\end{array}$ & $\begin{array}{r}418 \\
334 \\
3364 \\
979\end{array}$ & & & & \\
\hline Lower Muddy River drainage area & 801 & -- & -- & ${ }^{7} 560$ & 70 \\
\hline $\begin{array}{l}\text { Garnet Valley (HA 216) } \\
\text { Hidden Valley (HA 217) } \\
\text { California Wash (HA 218) } \\
\text { Lower Moapa Valley (HA 220) }\end{array}$ & $\begin{array}{r}156 \\
80 \\
313 \\
252\end{array}$ & & & & \\
\hline Las Vegas Wash subbasin & 1,875 & ${ }^{9} 1,829$ & 98 & ${ }^{10} 850$ & 45 \\
\hline $\begin{array}{l}\text { Three Lakes Valley (HA 211) } \\
\text { Las Vegas Valley (HA 212) }\end{array}$ & $\begin{array}{r}311 \\
1,564\end{array}$ & & & & \\
\hline $\begin{array}{l}\text { Other subbasins } \\
\text { Virgin River subbasin (HA 221, 222) } \\
\text { Ephemeral tributaries (HA 213-215, 223, 224) }\end{array}$ & $\begin{array}{l}{ }_{11}^{11,099} \\
11_{2,172}\end{array}$ & $\begin{array}{c}125,980 \\
-\end{array}$ & $\begin{array}{l}-- \\
--\end{array}$ & $\begin{array}{r}{ }^{13} 1,100 \\
1,200\end{array}$ & $\begin{array}{r}100 \\
55\end{array}$ \\
\hline
\end{tabular}

${ }^{1}$ Hydrographic-area numbers, names, and areas from Rush (1968a).

2 U.S. Geological Survey digital data base, 1:750,000, 1994, rounded to two significant figures. Areas include Nevada parts of subbasins only.

${ }^{3}$ Nevada part of area only. About 5 square miles additional area of Muddy River subbasin are in Utah.

${ }^{4}$ Muddy River above Lake Mead near Overton; includes Utah part of subbasin; approximate area (Robert E. Bostic, U.S. Geological Survey, oral commun., 1994).

5 Paharangat Wash near Moapa (Robert E. Bostic, written commun., 1994).

${ }^{6}$ Meadow Valley Wash near Rox (U.S. Geological Survey, 1994, p. 69).

7 Approximately 130 square miles of public lands are in noncontributing hydrographic areas; approximately 430 square miles of public lands contribute to Colorado River.

${ }^{8}$ Noncontributing part of Colorado River Basin.

${ }^{9}$ Las Vegas Wash near Henderson; includes 1,518 square miles that contribute directly to surface runoff (U.S. Geological Survey, 1993, p. 89), plus noncontributing Three Lakes Valley.

10 Approximately 120 square miles of public lands are in noncontributing hydrographic area; approximately 730 square miles of public lands contribute to Colorado River.

11 Nevada part of area only.

12 Virgin River above Halfway Wash near Riverside (U.S. Geological Survey, 1994, p. xii).

13 All but about 40 square miles in Nevada part of subbasin are public lands. 

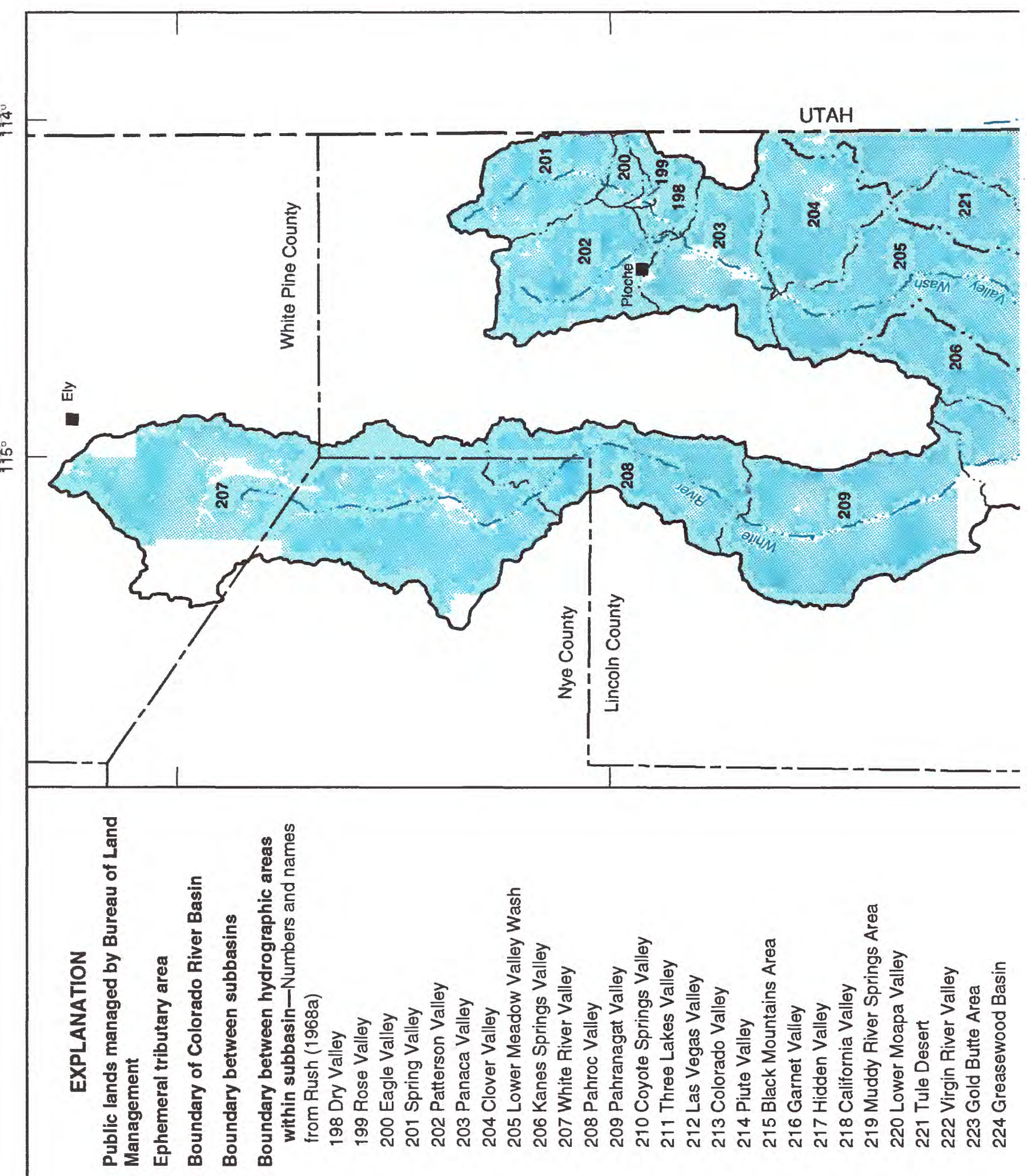

口目|! 
㐫
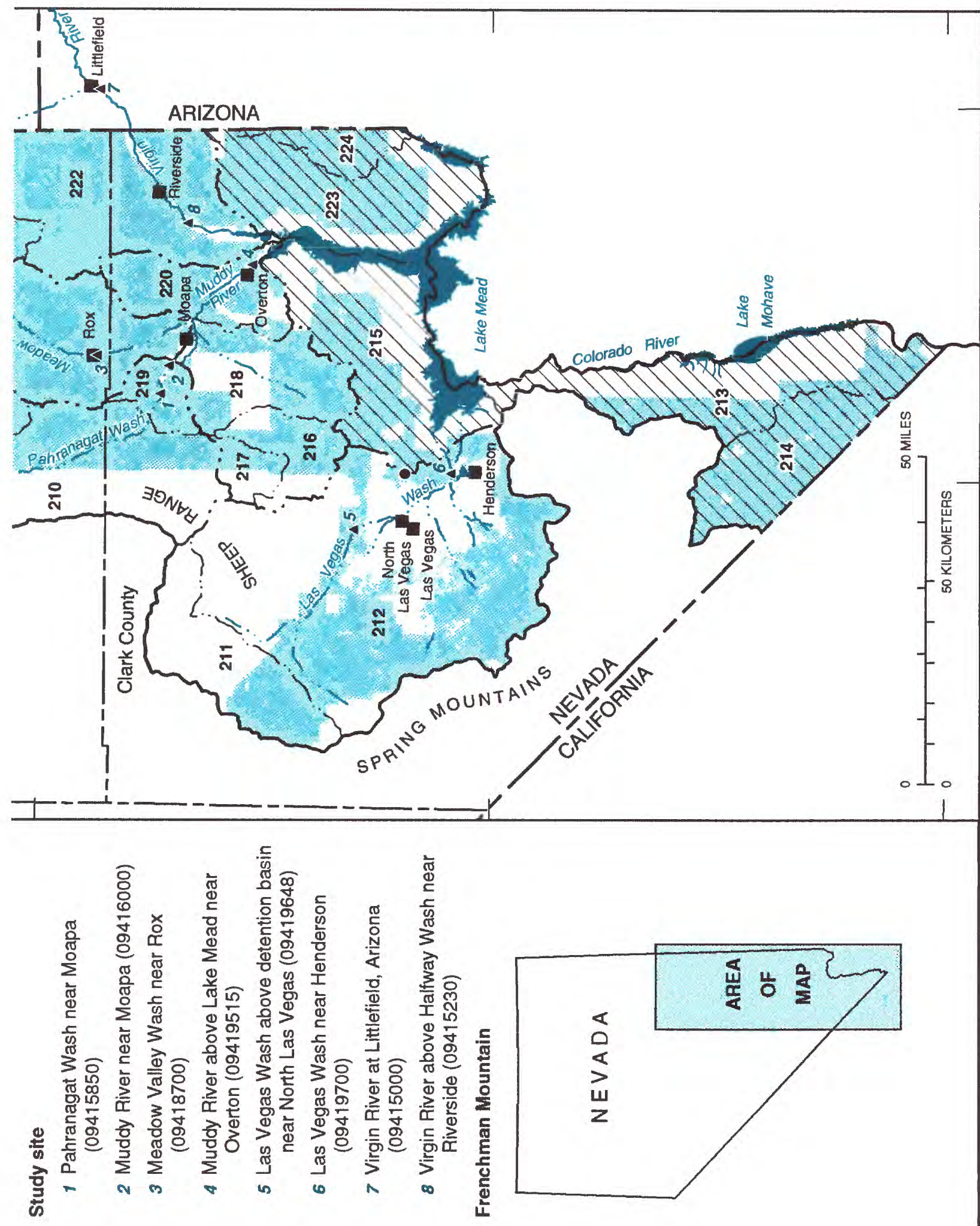
The Pahranagat Wash study site (Pahranagat Wash near Moapa) is about 9 mi northwest of Moapa (fig. 1). Ephemeral runoff in Pahranagat Wash, a narrow channel that connects the lower part of the White River to the upper part of the Muddy River, flows past the gage. This study site is upstream from agricultural development. The drainage area upstream from the site is about 3,830 $\mathrm{mi}^{2}$ (Robert E. Bostic, U.S. Geological Survey, written commun., 1994), and the Pahranagat Wash-White River drainage area is about 3,865 $\mathrm{mi}^{2}$ (table 1), all within Nevada. For water years 1990-93, annual streamflow averaged $0.92 \mathrm{ft}^{3} / \mathrm{s}$ (table 2) and ranged from $0.21 \mathrm{ft}^{3} / \mathrm{s}$ for 1992 to $1.5 \mathrm{ft}^{3} / \mathrm{s}$ for 1991 and 1993 (fig. 2).

The Muddy River study site near Moapa is about 5 mi northwest of Moapa and $4 \mathrm{mi}$ southeast and downstream from the Pahranagat Wash study site (fig. 1). (Intermittent surface runoff in Pahranagat Wash may not reach the Muddy River near Moapa except during infrequent periods of high flow.) The average annual streamflow of about $43 \mathrm{ft}^{3} / \mathrm{s}$, for water years $1913-93$ as reported by the USGS $(1994$, p. 65$)$, includes a diversion of $3.5 \mathrm{ft}^{3} / \mathrm{s}$ upstream from the site during water years 1975-77 for cooling water at a power generation facility. The diversion began in 1975 and continued at least through 1993; however, for water years 1977-93, the streamflow records do not include that diversion.

For water years 1989-93, the annual streamflow averaged $37 \mathrm{ft}^{3} / \mathrm{s}$ (table 2) and ranged from $34 \mathrm{ft}^{3} / \mathrm{s}$ for 1989 to $40 \mathrm{ft}^{3} / \mathrm{s}$ for 1993 (fig. 2).

Streamflow at the Muddy River study site near Moapa is primarily from subsurface flow discharging at numerous springs upstream from the site. Water discharging from the springs is thought to be a mixture of water recharged from the White River flow system (40 percent), the Sheep Range (38 percent), and the southern Meadow Valley Wash flow system ( 22 percent), on the basis of stable-isotope composition (Thomas and Welch, in press). The White River flow system includes the northern part of the Pahranagat Wash-White River drainage area. The Sheep Range borders the southwest side of the Pahranagat Wash-White River drainage area.

Some surface runoff contributes to the streamflow at the study site and may increase the average streamflow for some years (see 1993 in table 2). The long-term average streamflow, however, is probably increased only slightly by surface runoff. For the purposes of this report, all flow at the Muddy River study site is considered subsurface flow.

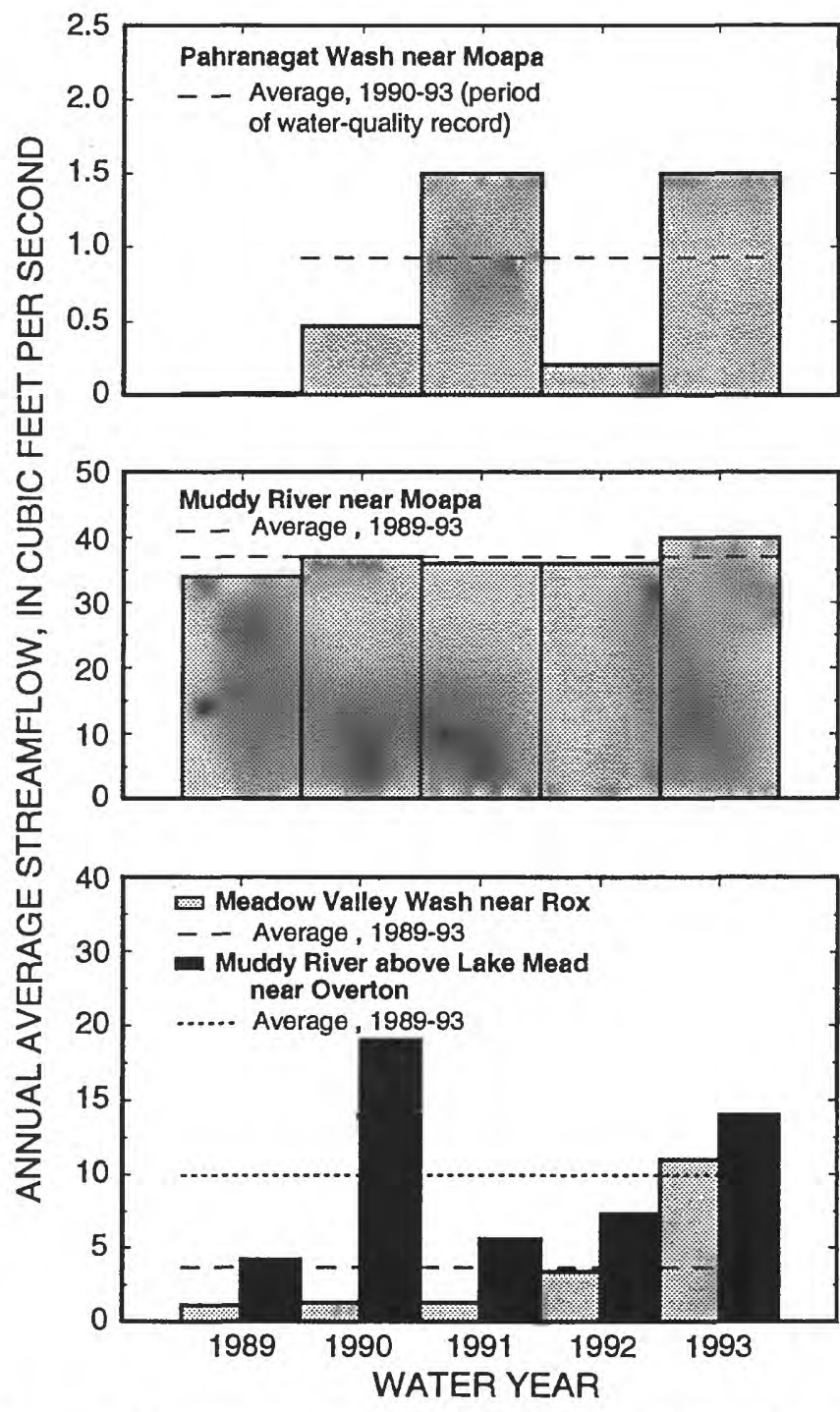

Figure 2. Average streamflow at study sites in Muddy River subbasin, Nevada, 1989-93.

The Meadow Valley Wash study site (Meadow Valley Wash near Rox) is about 14 mi north of Moapa (fig. 1) and is upstream from agricultural development. Streamflow is perennial at the site, but it is intermittent in some upstream and downstream reaches of the wash. Streamflow infiltrates about $3 \mathrm{mi}$ downstream, and only during extreme snowmelt runoff or intense storms does surface runoff reach the Muddy River. Streamflow at Meadow Valley Wash near Rox is a combination of discharge from a spring several miles upstream from the site and surface runoff. However, all streamflow at the study site is assumed to be surface runoff for this report. Most of the surface runoff from the Meadow Valley Wash subbasin flows past this site. The drainage area 
Table 2. Annual average streamflow, specific conductance, dissolved-solids concentration, and dissolved-solids load at selected study sites in Nevada

[Values rounded to two significant figures. Abbreviations and symbol: $\mathrm{ft}^{3} / \mathrm{s}$, cubic feet per second; $\mathrm{mg} / \mathrm{L}$, milligrams per liter; $\mu \mathrm{S} / \mathrm{cm}$, microsiemens per centimeter at 25 degrees Celsius; --, data not available]

\begin{tabular}{|c|c|c|c|c|c|c|}
\hline \multirow[b]{2}{*}{ Water year ${ }^{1}$} & \multicolumn{2}{|c|}{ Streamflow } & \multicolumn{2}{|c|}{ Specific conductance } & \multirow{2}{*}{$\begin{array}{c}\text { Average } \\
\text { dissolved- } \\
\text { sollds } \\
\text { concentration }{ }^{2} \\
\text { (mg/L) }\end{array}$} & \multirow{2}{*}{$\begin{array}{l}\text { Average } \\
\text { dissolved- } \\
\text { solids load } \\
\text { (tons per } \\
\text { year) }\end{array}$} \\
\hline & $\begin{array}{c}\text { Average } \\
\left(\mathrm{ft}^{3} / \mathrm{s}\right)\end{array}$ & $\begin{array}{l}\text { Number of } \\
\text { days of flow }\end{array}$ & $\begin{array}{l}\text { Average } \\
(\mu \mathrm{S} / \mathrm{cm})\end{array}$ & $\begin{array}{l}\text { Number of } \\
\text { days of } \\
\text { record }\end{array}$ & & \\
\hline
\end{tabular}

Pahranagat Wash near Moapa

[average dissolved-solids concentration $=(0.464)$ (average specific conductance) +50 ]

\begin{tabular}{|c|c|c|c|c|c|c|}
\hline 1989 & 0.01 & 1 & -- & 0 & -- & Not determined \\
\hline 1990 & .47 & 7 & 230 & 4 & 160 & 74 \\
\hline 1991 & 1.5 & 11 & 240 & 11 & 160 & 240 \\
\hline 1992 & .21 & 9 & 220 & 9 & 150 & 31 \\
\hline 1993 & 1.5 & 13 & 210 & 13 & 150 & 220 \\
\hline age, 1990-93 & .92 & & 220 & & 160 & 140 \\
\hline
\end{tabular}

\section{Muddy River near Moapa}

[average dissolved-solids concentration $=(0.680)$ (average specific conductance)-46]

$\begin{array}{lrrrrrr}1989 & 34 & 365 & 990 & 148 & 630 & 21,000 \\ 1990 & 37 & 365 & 1,000 & 270 & 630 & 23,000 \\ 1991 & 36 & 365 & 1,000 & 285 & 630 & 22,000 \\ 1992 & 36 & 366 & 1,000 & 293 & 630 & 22,000 \\ 1993 & 40 & 365 & 1,000 & 96 & 630 & 25,000 \\ \text { rage, } 1989-93 & 37 & & 1,000 & & 630 & 23,000\end{array}$

\section{Meadow Valley Wash near Rox}

[average dissolved-solids concentration $=(0.736)$ (average specific conductance)-80]

$\begin{array}{lrrrrrr}1989 & 1.1 & 365 & 1,500 & 329 & 1,000 & 1,100 \\ 1990 & 1.3 & 365 & 1,500 & 336 & 1,000 & 1,300 \\ 1991 & 1.3 & 365 & 1,500 & 308 & 1,000 & 1,300 \\ 1992 & 3.4 & 366 & 41,400 & 261 & 950 & 3,200 \\ 1993 & 11 & 365 & 1,500 & 341 & 1,000 & 11,000 \\ \text { rage, } 1989-93 & 3.6 & & 1,500 & & 990 & 3,600\end{array}$

Las Vegas Wash above detention basin near North Las Vegas

[average dissolved-solids concentration $=(0.633)$ (average specific conductance)-8.3]

\begin{tabular}{lrrrrrr}
1989 & 0.018 & 3 & - & 0 & -- & Not determined \\
1990 & .011 & 4 & 160 & 2 & 93 & 1.0 \\
1991 & .008 & 4 & -- & 0 & -- & Not determined \\
1992 & .020 & 6 & 170 & 6 & 100 & 2.0 \\
1993 & .023 & 4 & 110 & 2 & 61 & 1.4 \\
& .018 & & 150 & & 85 & 1.5 \\
\hline
\end{tabular}

\footnotetext{
${ }^{1}$ Water year begins October 1 , ends September 30 , and is designated by calendar year in which it ends.

${ }^{2}$ Computed from annual average specific conductance, using regression equation shown in brackets after each site name.

${ }^{3}$ Average dissolved-solids load $=$ (average dissolved-solids concentration)(average streamflow) $(0.985)$.

${ }^{4}$ For purposes of this report, 82 of 105 missing daily specific-conductance values were estimated using regression equation: specific conductance $=($ streamflow $)(602)+904 ; \mathrm{r}^{2}=0.65$. This equation was developed for flows ranging from 0.56 to $1.6 \mathrm{ft}^{3} / \mathrm{s}$.
} 
upstream from the study site is $2,384 \mathrm{mi}^{2}$ (U.S. Geological Survey, 1994, p. 69), and the overall Meadow Valley Wash drainage area in Nevada is 2,559 $\mathrm{mi}^{2}$ (table 1). About $5 \mathrm{mi}^{2}$ of the Meadow Valley Wash drainage is in Utah. For water years 1989-93, annual streamflow averaged $3.6 \mathrm{ft}^{3} / \mathrm{s}$ (table 2), and ranged from $1.1 \mathrm{ft}^{3} / \mathrm{s}$ for 1989 to $11 \mathrm{ft}^{3} / \mathrm{s}$ for 1993 (fig. 2).

The Muddy River study site above Lake Mead, about 1.9 mi southeast of Overton, is near the mouth of the Muddy River, which flows into Lake Mead (an impoundment of the Colorado River). Most surface runoff from the Muddy River subbasin flows past the site. The drainage area for the study site is about 7,230 $\mathrm{mi}^{2}$ (Robert E. Bostic, U.S. Geological Survey, written commun., 1994), including about $5 \mathrm{mi}^{2}$ in Utah. About 7,225 $\mathrm{mi}^{2}$ of the Muddy River subbasin is in Nevada (table 1). For water years 1979-93, annual streamflow averaged $9.2 \mathrm{ft}^{3} / \mathrm{s}$; for $1989-93$, annual streamflow averaged $10 \mathrm{ft}^{3} / \mathrm{s}$ (table 3 ).

The annual average streamflows in the Muddy River near Moapa (water years 1977-93) and in the Muddy River above Lake Mead near Overton (water years 1979-93) are shown in figure 4. Average annual streamflow near Moapa (water years 1977-93) was about four times greater than at Overton (water years 1979-93).

The Las Vegas Wash subbasin is drained by Las Vegas Wash (fig. 1). The study sites in the Las Vegas Wash subbasin are Las Vegas Wash above detention basin (flood control) near North Las Vegas and Las Vegas Wash near Henderson.

The Las Vegas Wash study site near North Las Vegas (fig. 1) is upstream from urban development. Streamflow is ephemeral, and small flows may be contained in a manmade flood detention basin about $1 / 2 \mathrm{mi}$ downstream from the site. Larger streamflows reach and pass through the detention-basin outlet. For water years 1989-93, annual streamflow averaged $0.016 \mathrm{ft}^{3} / \mathrm{s}$ and ranged from $0.008 \mathrm{ft}^{3} / \mathrm{s}$ for 1991 to $0.023 \mathrm{ft}^{3} / \mathrm{s}$ for 1993 (fig. 3).

The Las Vegas Wash study site near Henderson is about $6.0 \mathrm{mi}$ upstream from Lake Mead and $3.5 \mathrm{mi}$ north of Henderson, and includes surface runoff, subsurface return flows from urban landscape irrigation, and treated sewage effluent from the urbanized parts of Las Vegas Valley. The drainage area upstream from the study site is about $1,829 \mathrm{mi}^{2}$ (table 1; U.S. Geological Survey, 1993, p. 89), all within Nevada. For water years 1977-92, annual streamflow averaged $110 \mathrm{ft}^{3} / \mathrm{s}$ and for water years 1989-92, annual streamflow averaged $150 \mathrm{ft}^{3} / \mathrm{s}$ (table 3 ), reflecting a continuous trend in increasing surface returns from the expanding urban areas. The annual average stream-flows in Las Vegas Wash near Henderson (water years 1977-93), shown in figure 4, are based on continuous streamflow data from 1977 to 1988 and periodic streamflow measurements or estimates from 1989 to 1992 (U.S. Geological Survey, 1978-93). Annual dissolved-solids concentrations are based on periodic analysis of water samples. Some subsurface flow and surface runoff may bypass the study site, but the relatively small amount was disregarded for this study.

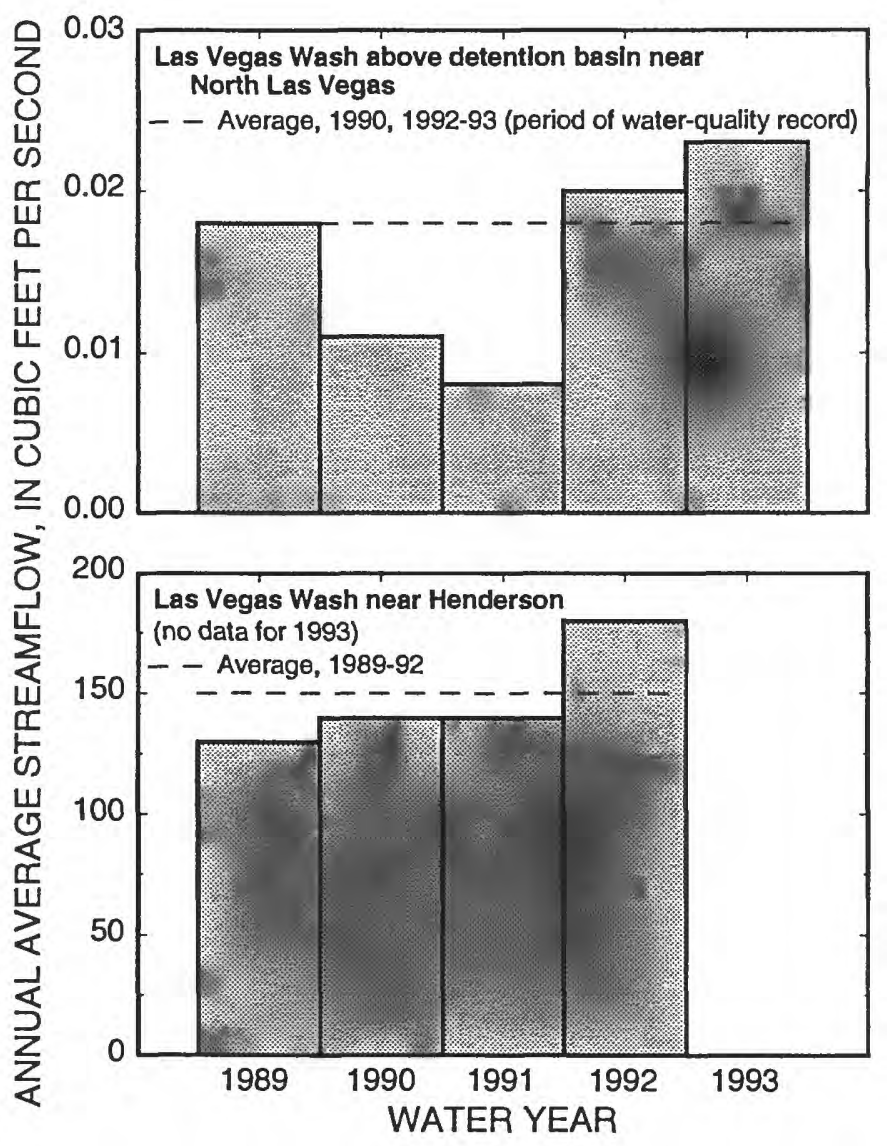

Figure 3. Average streamflow at study sites in Las Vegas Wash subbasin, Nevada, 1989-93. 
Table 3. Data on drainage area, streamflow, and dissolved solids at study sites in Nevada

[Streamflow and dissolved-solids values rounded to two significant figures. Abbreviation and symbol: $\mathrm{ft}^{3} / \mathrm{s}$, cubic feet per second; -- , data not available for part of period]

\begin{tabular}{|c|c|c|c|c|c|c|}
\hline \multirow[b]{2}{*}{$\begin{array}{l}\text { Study site name and } \\
\text { station number }\end{array}$} & \multirow[b]{2}{*}{$\begin{array}{c}\text { Drainage } \\
\text { area } \\
\text { (square } \\
\text { miles) }\end{array}$} & \multicolumn{2}{|c|}{ Streamflow } & \multicolumn{3}{|c|}{ Dissolved solids } \\
\hline & & $\begin{array}{l}\text { Average } \\
\text { annual } \\
\left(\mathrm{ft}^{3} / \mathrm{s}\right)\end{array}$ & $\begin{array}{l}\text { Perlod } \\
\text { of } \\
\text { record }\end{array}$ & $\begin{array}{c}\text { Average } \\
\text { annual load } \\
\text { (tons per } \\
\text { year) }\end{array}$ & $\begin{array}{l}\text { Period } \\
\text { of } \\
\text { record }\end{array}$ & $\begin{array}{l}\text { Average } \\
\text { annual yield } \\
\text { (tons per } \\
\text { square mlle) }\end{array}$ \\
\hline \multicolumn{7}{|l|}{ Muddy River subbasin } \\
\hline $\begin{array}{l}\text { Pahranagat Wash near Moapa } \\
(09415850)\end{array}$ & 3,830 & 0.92 & $1990-93$ & 140 & $1990-93$ & 0.036 \\
\hline $\begin{array}{l}\text { Muddy River near Moapa } \\
(09416000)\end{array}$ & ${ }^{2} 3,820$ & $\begin{array}{l}38 \\
37\end{array}$ & $\begin{array}{l}1977-93 \\
1989-93\end{array}$ & 23,000 & $1989-93$ & $\overline{6}-\overline{0}$ \\
\hline $\begin{array}{l}\text { Meadow Valley Wash near Rox } \\
(09418700)\end{array}$ & 2,384 & 3.6 & $1989-93$ & 3,600 & $1989-93$ & 1.5 \\
\hline $\begin{array}{l}\text { Muddy River above Lake Mead } \\
\text { near Overton (09419515) }\end{array}$ & 7,230 & $\begin{array}{l}9.2 \\
10\end{array}$ & $\begin{array}{l}1979-93 \\
1989-93\end{array}$ & $\begin{array}{l}21,000 \\
21,000\end{array}$ & $\begin{array}{l}1979-93 \\
1989-93\end{array}$ & $\begin{array}{l}2.9 \\
2.9\end{array}$ \\
\hline \multicolumn{7}{|l|}{ Las Vegas Wash subbasin } \\
\hline $\begin{array}{l}\text { Las Vegas Wash above detention } \\
\text { basin near North Las Vegas } \\
\text { (09419648) }\end{array}$ & (3) & ${ }^{4} .67$ & $1963-78$ & 59 & $\begin{array}{l}1990, \\
1992-93\end{array}$ & .045 \\
\hline $\begin{array}{l}\text { Las Vegas Wash near Henderson } \\
\quad(09419700)\end{array}$ & 1,829 & $\begin{array}{l}110 \\
150\end{array}$ & $\begin{array}{l}1977-92 \\
1989-92\end{array}$ & $\begin{array}{l}170,000 \\
210,000\end{array}$ & $\begin{array}{l}1977-92 \\
1989-92\end{array}$ & $\begin{array}{r}98 \\
110\end{array}$ \\
\hline \multicolumn{7}{|l|}{ Virgin River subbasin } \\
\hline $\begin{array}{l}\text { Virgin River at Littlefield } \\
\quad(09415000)\end{array}$ & $5_{5,090}$ & $\begin{array}{l}300 \\
360\end{array}$ & $\begin{array}{l}1978-93 \\
1978-86\end{array}$ & $\begin{array}{l}560,000 \\
640,000\end{array}$ & $\begin{array}{l}1978-93 \\
1978-86\end{array}$ & $\begin{array}{l}110 \\
130\end{array}$ \\
\hline $\begin{array}{l}\text { Virgin River above Halfway Wash } \\
\text { near Riverside }(09415230)\end{array}$ & ${ }^{5} 5,980$ & 360 & $1978-86$ & 710,000 & $1978-86$ & 120 \\
\hline
\end{tabular}

${ }^{1}$ Eight-digit number is used to identify each study site. For example, station number 09419700 consists of two-digit part number (09) followed by six-digit downstream-order number (419700). Part refers to drainage area or group of areas that is generally regional in extent. Records in this report are for sites in Part 09 (Colorado River Basin). Downstream-order number is assigned according to geographic location of station in drainage network; larger number stations are downstream from smaller number stations. All sites are in Nevada, except Virgin River at Littlefield, which is in Arizona.

2 Approximate area (U.S. Geological Survey, 1994, p. 65).

3 Area not determined.

${ }^{4}$ Average streamflow is from earlier, longer term records for gaging station about 6 miles downstream from study site (station 09419650); is thought to be more representative of flow in this reach of Las Vegas Wash (see text).

5 Includes parts of Arizona, Utah, and Nevada. 


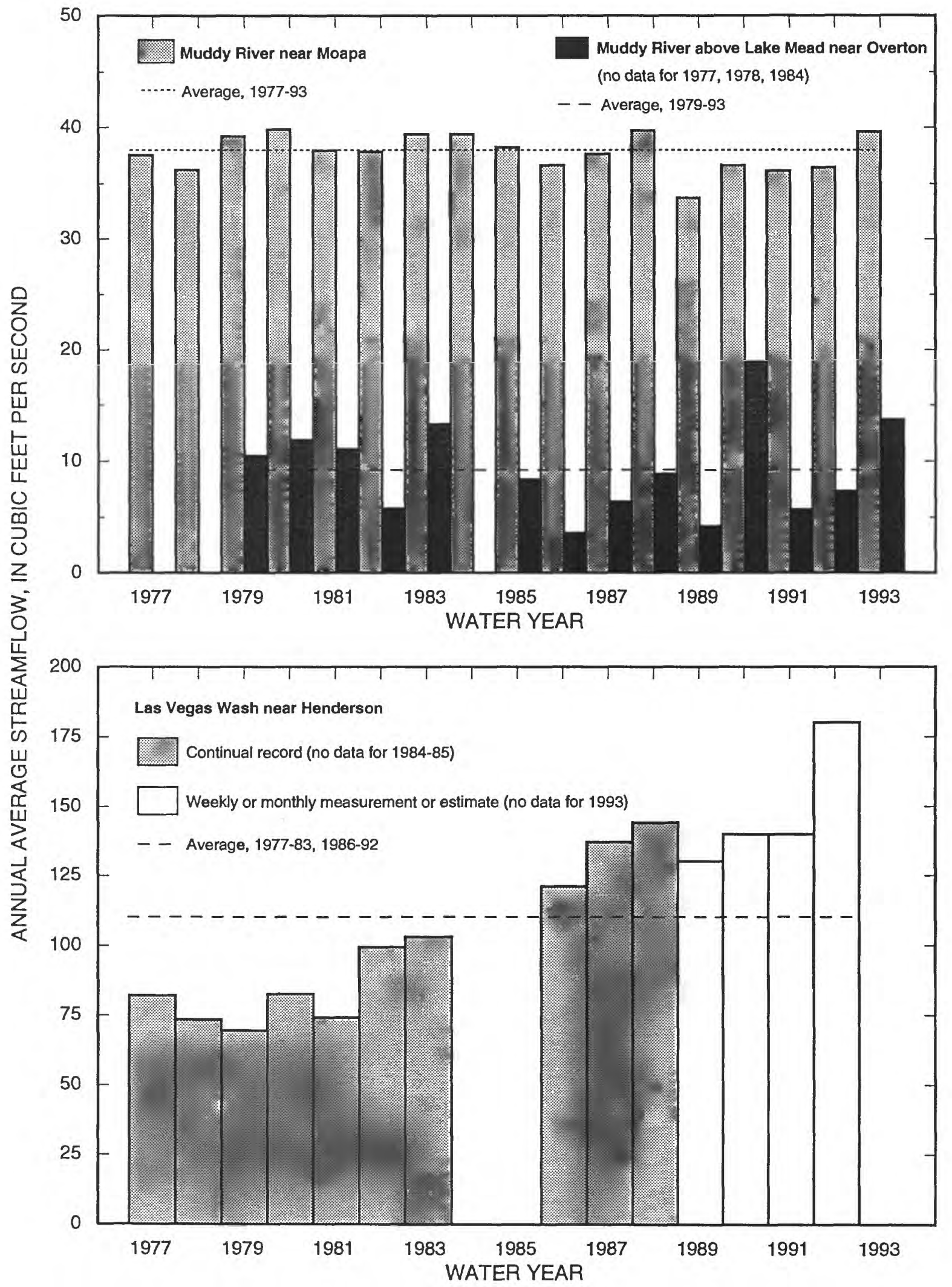

Figure 4. Annual average streamflow for Muddy River and Las Vegas Wash, Nevada, at four study sites with long-term record. 


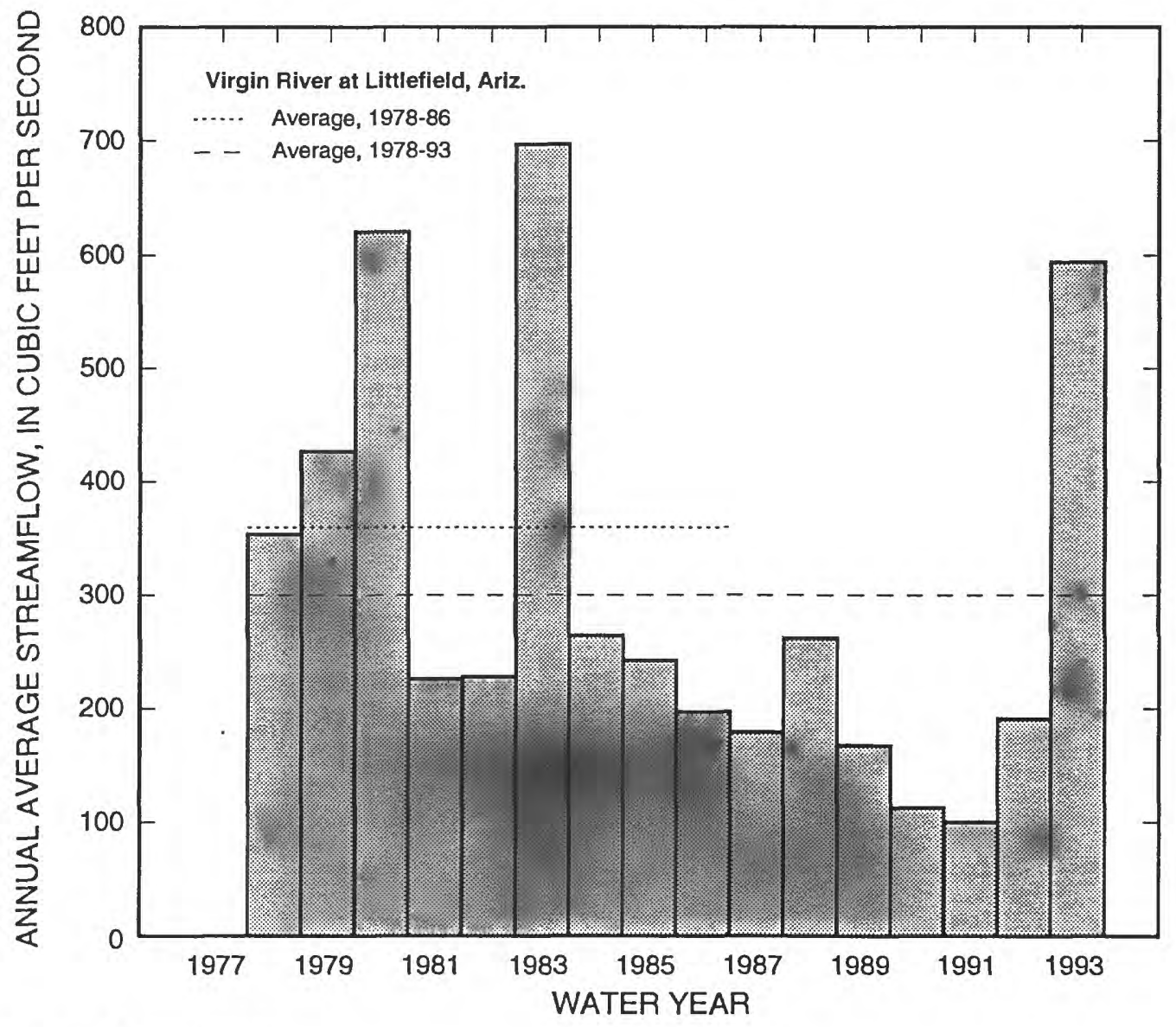

Figure 4. Continued.

The Virgin River study site at Littlefield is about $36 \mathrm{mi}$ upstream from Lake Mead and 0.4 mi upstream from Littlefield, Ariz. The drainage area upstream from the study site is about $5,090 \mathrm{mi}^{2}$ (U.S. Geological Survey, 1993, p. 52), including parts of Arizona and Utah (table 3). Annual streamflow averaged $300 \mathrm{ft}^{3} / \mathrm{s}$ for water years 1978-93 and annual streamflow averaged $360 \mathrm{ft}^{3} / \mathrm{s}$ for water years 1978-86 (table 3). The annual average streamflows in Virgin River at Littlefield (water years 1978-93), shown in figure 4, are based on continuous streamflow data from 1978 to 1993 (U.S. Geological Survey, 1979-94).

The Virgin River study site above Half way Wash is about $8 \mathrm{mi}$ upstream from Lake Mead. The drainage area upstream from the study site is about $5,980 \mathrm{mi}^{2}$ (U.S. Geological Survey, 1994, p. xii). For water years 1978-86; periodically measured streamflow averaged $360 \mathrm{ft}^{3} / \mathrm{s}$ (table 3; U.S. Geological Survey, 1979-88).
Ephemeral tributaries in Nevada that drain to the Colorado River and its impoundments lie within the following hydrographic areas (fig. 1): Colorado Valley (area 213), Piute Valley (214), Black Mountains Area (215), Gold Butte Area (223), and Greasewood Basin (224). All but Piute Valley and Greasewood Basin drain directly to the river or its impoundments in Nevada. In contrast, surface runoff and subsurface flow in Piute Valley drain southward into California before reaching the river; in Greasewood Basin, the runoff and subsurface flow drain eastward into Arizona before reaching the river. This report deals only with the Nevada parts of the two hydrographic areas. However, the dissolved-solids loads generated in Nevada are assumed to ultimately reach the river in California and Arizona, respectively. 
Ranges in recorded streamflow and specific conductance at the four sites that were established as part of this study are listed below for the overall periods during which specific-conductance data are available.

[Abbreviations: e, estimated; $\mu \mathrm{S} / \mathrm{cm}$, microsiemens per centimeter at 25 degrees Celsius]

\begin{tabular}{|c|c|c|c|c|}
\hline \multirow[b]{2}{*}{$\begin{array}{c}\text { Study Site } \\
\text { (water years) }\end{array}$} & \multicolumn{2}{|c|}{$\begin{array}{l}\text { Streamflow } \\
\text { (cubic feet } \\
\text { per second) }\end{array}$} & \multicolumn{2}{|c|}{$\begin{array}{c}\text { Specific } \\
\text { conductance } \\
(\mu \mathrm{S} / \mathrm{cm})\end{array}$} \\
\hline & $\begin{array}{l}\text { Maximum } \\
\text { instan- } \\
\text { taneous }\end{array}$ & $\begin{array}{c}\text { Minimum } \\
\text { daily }\end{array}$ & $\begin{array}{l}\text { Maximum } \\
\text { recorded }\end{array}$ & $\begin{array}{l}\text { MInimum } \\
\text { recorded }\end{array}$ \\
\hline $\begin{array}{l}\text { Pahranagat Wash } \\
\text { near Moapa } \\
\text { (1990-93) }\end{array}$ & e3,350 & 0.00 & 550 & 109 \\
\hline $\begin{array}{c}\text { Muddy River } \\
\text { near Moapa } \\
(1989-93)\end{array}$ & $e 5,760$ & 26 & 1,490 & 496 \\
\hline $\begin{array}{l}\text { Meadow Valley } \\
\text { Wash near Rox } \\
(1989-93)\end{array}$ & e1,620 & .14 & 7,460 & 204 \\
\hline $\begin{array}{l}\text { Las Vegas Wash } \\
\text { above detention } \\
\text { basin near North } \\
\text { Las Vegas } \\
(1990,1992-93)\end{array}$ & e278 & .00 & 286 & 79 \\
\hline
\end{tabular}

\section{Methods Used to Estimate Dissolved-Solids Concentration, Load, and Yield}

Annual dissolved-solids concentrations can be estimated from measurements of specific conductance and dissolved-solids concentration of periodically collected samples. Conductance is the ability of a solution to conduct an electrical current due to the presence of dissolved, ionized constituents. As the concentration of dissolved constituents increases, the conductance of the solution also increases. The specific-conductance measurement, therefore, is an approximate measure of the dissolved-solids concentration (Hem, 1985, p. 6669).

Water samples were collected intermittently at Pahranagat Wash near Moapa, Muddy River near Moapa, Meadow Valley Wash near Rox, and Las Vegas Wash near North Las Vegas and analyzed for dissolved-solids concentration, determined by residue upon evaporation at $180^{\circ} \mathrm{C}$, at the USGS National Water-Quality Laboratory in Arvada, Colo. Specific conductance of the sample also was measured at the laboratory. Streamflow data and specific-conductance data were recorded half-hourly at Pahranagat Wash near Moapa and Las Vegas Wash near North Las Vegas and hourly at Muddy River near Moapa and Meadow Valley Wash near Rox (Gortsema, 1993, p. 2). Specific conductance was not recorded for 1989 at Pahranagat Wash near Moapa and for 1989 and 1991 at Las Vegas Wash near North Las Vegas, and thus, dissolved-solids concentration could not be computed for those years.

Measurements of specific conductance and dissolved-solids concentration were plotted for Pahranagat Wash near Moapa, Muddy River near Moapa, Meadow Valley Wash near Rox, and Las Vegas Wash near North Las Vegas to establish a regression line for each site. Specific conductance was plotted as the independent variable and dissolved-solids concentration as the dependent variable (fig. 5). An equation for each of the simple-regression lines was developed, which predicts a dissolved-solids concentration for a given specific-conductance measurement. The regression equations (shown in table 2) were then used to compute the annual average dissolved-solids concentration from the annual average specific conductance, which was determined from the continual specific-conductance record. The variance between the observed and predicted dissolved-solids concentration also was plotted to determine if the observed values were reasonably close to the predicted values. For the most part they were, which provides confidence in the use of simple-regression equations.

The annual average dissolved-solids load was computed for each year that average specific conductance and average streamflow data were available for Pahranagat Wash near Moapa, Muddy River near Moapa, Meadow Valley Wash near Rox, and Las Vegas Wash near North Las Vegas. The annual dissolvedsolids loads for each site were averaged to compute the average annual dissolved-solids load.

The average annual dissolved-solids yield (tons per square mile) was computed by dividing the average annual dissolved-solids load (tons per year) by the area upstream from the study site (square miles). This yield is assumed to represent the average annual yield for the entire drainage area and public lands within the drainage area, though it may not apply to small areas within the drainage area. Most values of loads and yields are rounded to two significant figures (a few are rounded to 


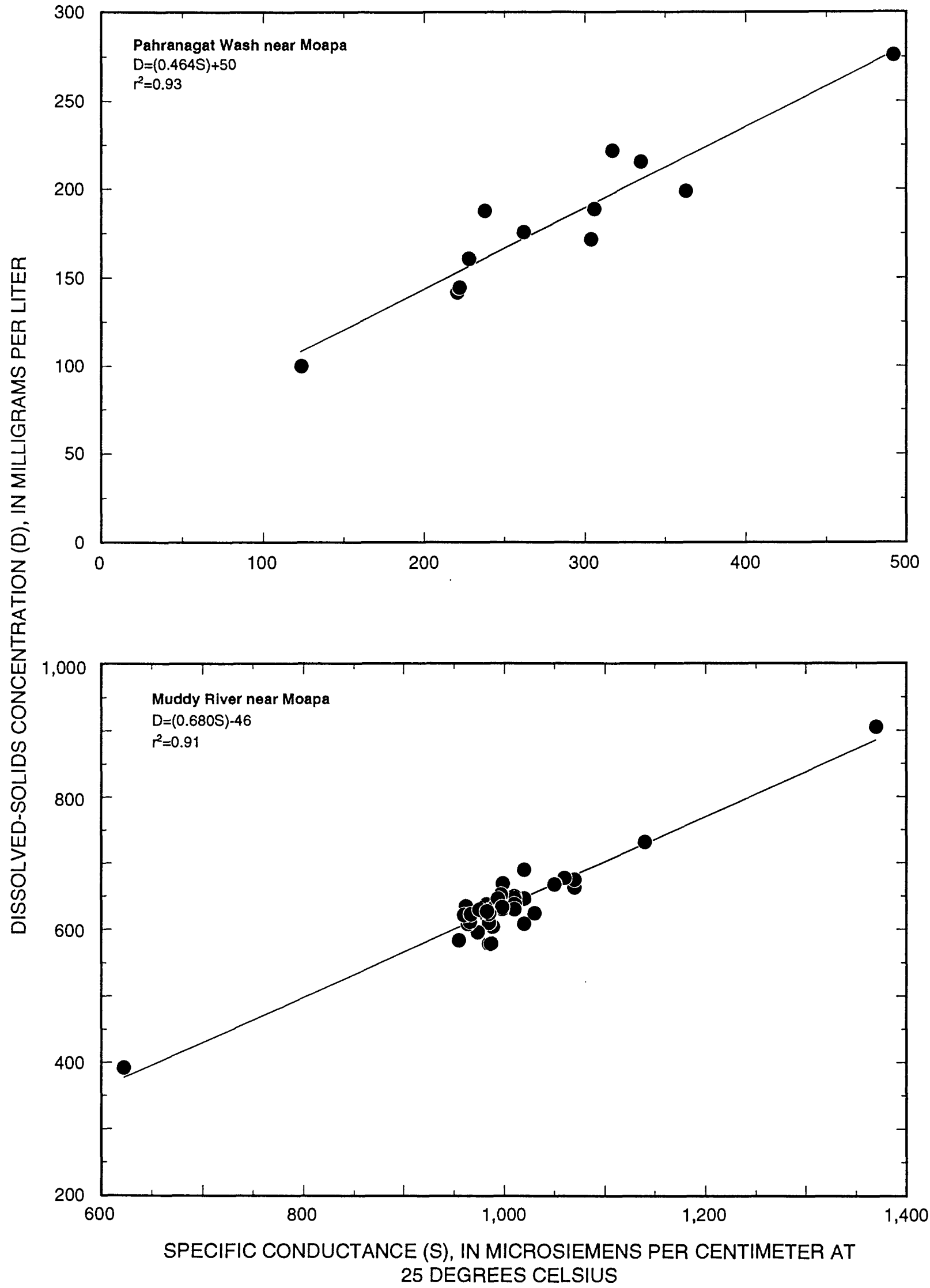

Figure 5. Relation between specific conductance and dissolved-solids concentrations for water samples collected at study sites in Nevada. Symbol: $r^{2}$, statistical coefficient indicating decimal percentage of total variation in dissolved solids that can be attributed to relation with specific conductance. 


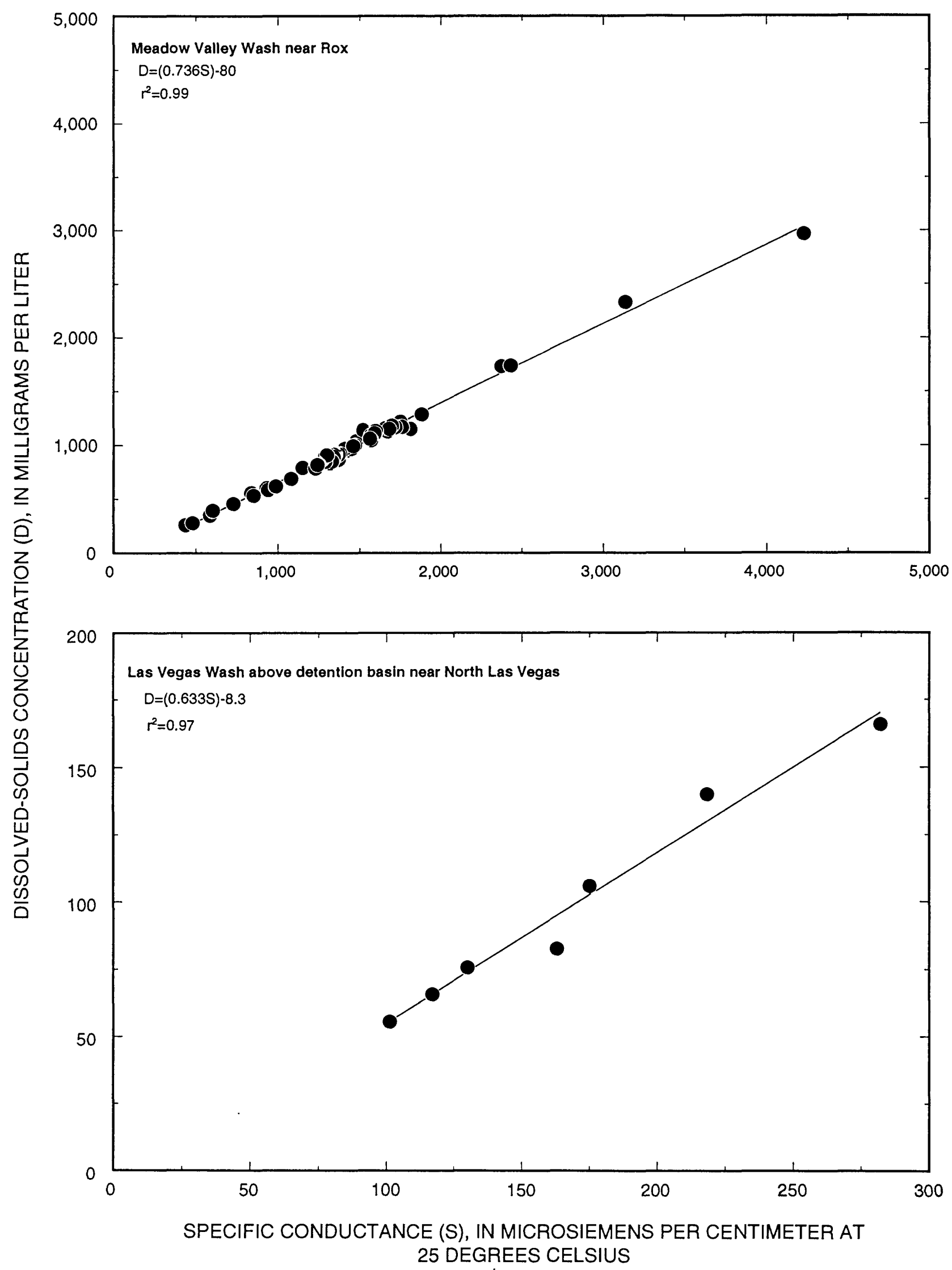

Figure 5. Continued. 
only one significant figure) because of measurement inaccuracies inherent in all hydrological data collection. Significant figures cited from references, however, are retained.

Water samples from Muddy River above Lake Mead near Overton have been analyzed periodically for dissolved-solids concentrations since 1979. Average annual dissolved-solids concentrations were computed for water years 1979-93 and 1989-93.

Water samples from Las Vegas Wash near Henderson were analyzed for dissolved-solids concentrations from 1970 to 1985 . In addition, 327 field measurements of specific conductance are available for 1970 to 1992, when data collection ceased. The field specific-conductance values were plotted against the dissolved-solids concentrations for 1970-85 to show their relation and develop a regression equation. Dissolved-solids concentrations were then computed from the field measurements of specific conductance for 1986-92, when only specific-conductance data were available. Average annual concentrations were computed for 1977-92 and 1989-92 (to approximately correspond to period of data available for the Muddy River and study period).

Water samples from Virgin River at Littlefield have been analyzed periodically for dissolved-solids concentrations since 1949. During water years 197893, dissolved-solids concentrations of water samples were determined from residue on evaporation at $180^{\circ} \mathrm{C}$ (ROE at $180^{\circ} \mathrm{C}$ ). Average dissolved-solids concentrations (ROE at $180^{\circ} \mathrm{C}$ ) were computed for water years 1978-93 and 1978-86 (to correspond with the period of data availability for the Virgin River above Halfway Wash near Riverside).

Water samples from Virgin River above Halfway Wash near Riverside were analyzed periodically for dissolved-solids concentrations during water years 1978-86. Average dissolved-solids concentrations were computed for the same period.

The dissolved-solids load, expressed in terms of tons per year in this report, was computed by using the equation: average dissolved-solids load, in tons per year=(average dissolved-solids concentration, in milligrams per liter)(average streamflow, in cubic feet per second) 0.985 .

\section{ESTIMATED DISSOLVED-SOLIDS CONCENTRATION, YIELD, AND LOAD}

\section{Muddy River Subbasin}

\section{Pahranagat Wash-White River Drainage Area}

For water years 1990-93, the estimated annual dissolved-solids concentration averaged $160 \mathrm{mg} / \mathrm{L}$ and ranged from $150 \mathrm{mg} / \mathrm{L}$ in 1992 and 1993 to $160 \mathrm{mg} / \mathrm{L}$ in 1990 and 1991 (table 2) for surface runoff at the Pahranagat Wash study site. Dissolved-solids load averaged 140 tons/yr for water years 1990-93 (table 2) and ranged from 31 tons in 1992 to 240 tons in 1991 (fig. 6). The average annual dissolved-solids yield was about $0.036 \mathrm{ton} / \mathrm{mi}^{2}$ (table 4 ). The yield was applied to the entire Pahranagat Wash-White River drainage area to determine the average dissolved-solids load of 140 tons/yr (table 4).

As was mentioned in the section "Description of Study Area and Study Sites," streamflow at the Muddy River study site near Moapa is thought to be a mixture of subsurface flow from the Pahranagat Wash-White River and Meadow Valley Wash drainage areas. On the basis of the contributions to springflow only, 78 percent or 18,000 tons/yr of the load for Muddy River near Moapa (total, 23,000 tons/yr; table 3) may originate in the Pahranagat Wash-White River drainage area (table 4). 1

Combined surface runoff and subsurface flow contributed an estimated total of 18,000 tons/yr (rounded) of dissolved-solids from the Pahranagat Wash-White River drainage area.

\footnotetext{
${ }^{1}$ Recharge in the White River flow system and recharge from the Sheep Range are thought to contribute about 40 percent and 38 percent, respectively, of the total springflow. Recharge in the Meadow Valley Wash drainage area is thought to contribute about 22 percent of the total springflow, on the basis of stableisotope composition (Thomas and Welch, in press). These percentages, as applied to dissolved-solids load, assume that the ground-water contribution from each recharge area has about the same dissolved-solids concentration. The validity of this assumption is unknown, given the lack of available data on ground-water quality.
} 

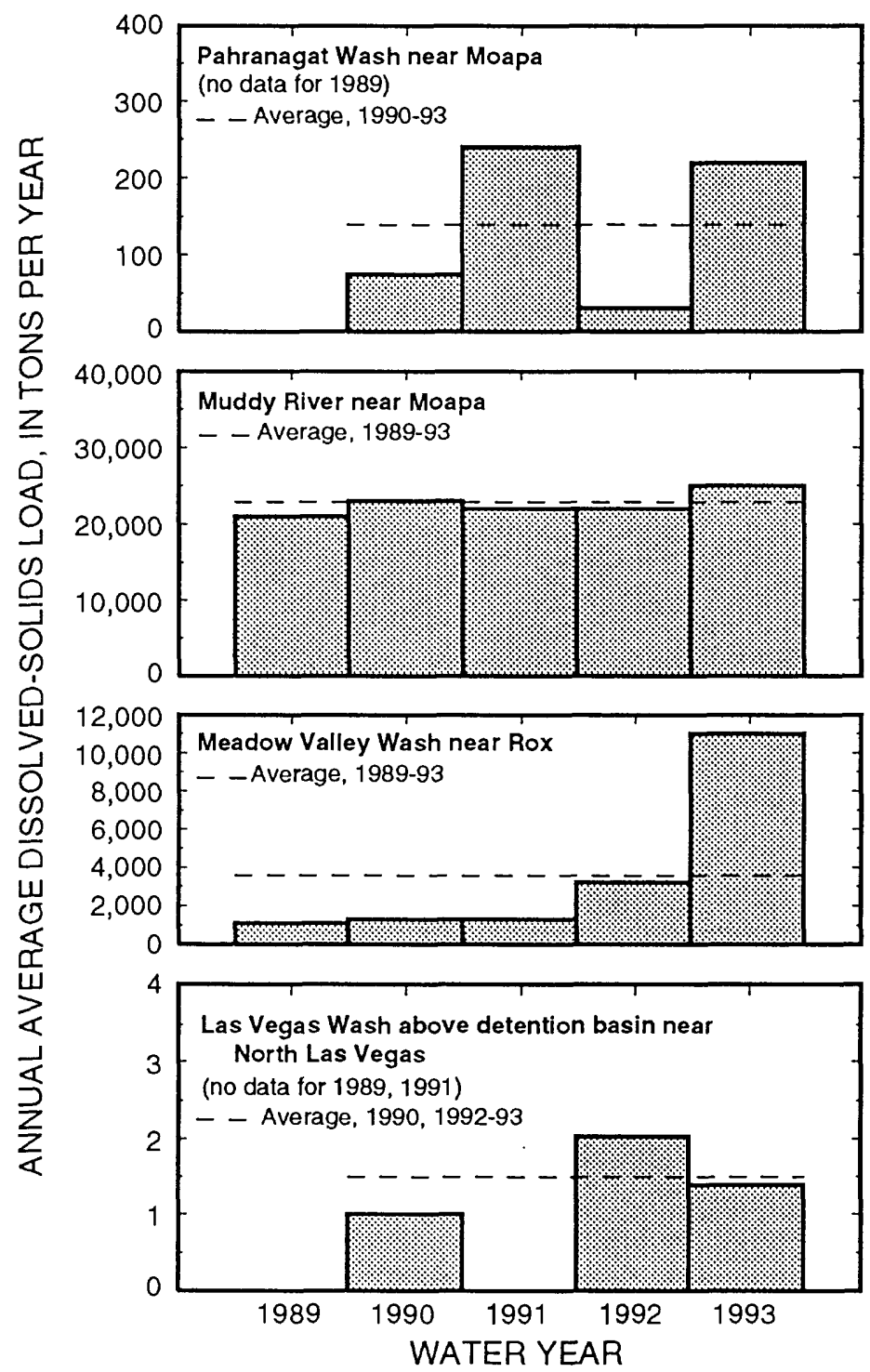

Figure 6. Annual average dissolved-solids load at four study sites in Nevada, 1989-93.

\section{Meadow Valley Wash Drainage Area}

For water years 1989-93, the estimated annual dissolved-solids concentrations averaged $990 \mathrm{mg} / \mathrm{L}$ and ranged from $950 \mathrm{mg} / \mathrm{L}$ in 1992 to $1,000 \mathrm{mg} / \mathrm{L}$ in 1989 91 and 1993 (table 2) for surface runoff at the Meadow Valley Wash study site. Dissolved-solids load averaged 3,600 tons/yr for water years 1989-93 (table 2) and ranged from 1,100 tons in 1989 to 11,000 tons in 1993 (fig. 6). The average annual dissolved-solids yield was about 1.5 tons $/ \mathrm{mi}^{2}$ (tables 3,4 ). The yield was applied to the entire Meadow Valley Wash drainage area to determine the average dissolved-solids load of 3,800 tons/yr (table 4).
On the basis of stable-isotope data, about 22 percent (Thomas and Welch, in press) or 5,000 tons/yr of the dissolved-solids load for Muddy River near Moapa may be contributed from the Meadow Valley Wash drainage area (table 4). Combined surface runoff and subsurface flow contributed an estimated total of 8,800 tons/yr of dissolved solids to the Muddy River subbasin from the Meadow Valley Wash drainage area (table 4).

\section{Lower Muddy River Drainage Area}

Additional surface runoff and subsurface flow in the lower Muddy River drainage area contributed dissolved solids to the dissolved-solids load of the Muddy River. The average annual dissolved-solids yield of $0.04 \mathrm{ton} / \mathrm{mi}^{2}$, determined from data collected at the Pahranagat Wash study site (0.036 ton $/ \mathrm{mi}^{2}$, rounded), was used to estimate the contribution of dissolvedsolids load of surface runoff in the lower Muddy River drainage area. About $565 \mathrm{mi}^{2}$ of the lower Muddy River drainage area contributes to the Colorado River. An annual yield of 0.04 ton $/ \mathrm{mi}^{2}$ for $565 \mathrm{mi}^{2}$ produces about 20 tons of dissolved solids from surface runoff (table 4). Rush (1968b, p. 26) estimated about 800 acre$\mathrm{ft} / \mathrm{yr}$ of subsurface flow from Garnet and Hidden Valleys (hydrographic areas 216 and 217, respectively) into the Muddy River subbasin. Data reported by Rush (1968b, p. 44) for wells and seeps in California Wash are used to determine an average dissolved-solids concentration of $1,300 \mathrm{mg} / \mathrm{L}$. Using these values, about 1,400 tons/yr (table 4) of dissolved solids were contributed by subsurface flow within the lower Muddy River drainage area. Combined surface runoff and subsurface flow in the lower Muddy River drainage area contributed an estimated 1,400 tons/yr (rounded) of dissolved solids to the Muddy River (table 4).

\section{Estimated Annual Dissolved-Solids Discharge to the Colorado River}

Dissolved-solids load of streamflow discharging to the Colorado River from the Muddy River subbasin averaged 21,000 tons/yr for water years 1989-93 (table 3). For comparison, an earlier study determined average dissolved-solids load of 19,770 tons/yr for 1979-83 in the Muddy River (Panian and others, 1987, p. 8). Rush (1968b, p. 44) lists dissolved-solids concentrations of ground-water samples from 12 sites in the lower Moapa Valley; the average concentration is $1,970 \mathrm{mg} / \mathrm{L}$. 
Table 4. Summary of average annual dissolved-solids yield, load, and discharge for drainage areas and subbasins in Nevada [Most dissolved-solids values rounded to two significant figures. Abbreviations: acre-ft/yr, acre-feet per year; $\mathrm{ft}^{3} / \mathrm{s}$, cubic feet per second; $\mathrm{mg} / \mathrm{L}$, milligrams per liter; tons $/ \mathrm{mi}^{2}$, tons per square mile; tons/yr, tons per year]

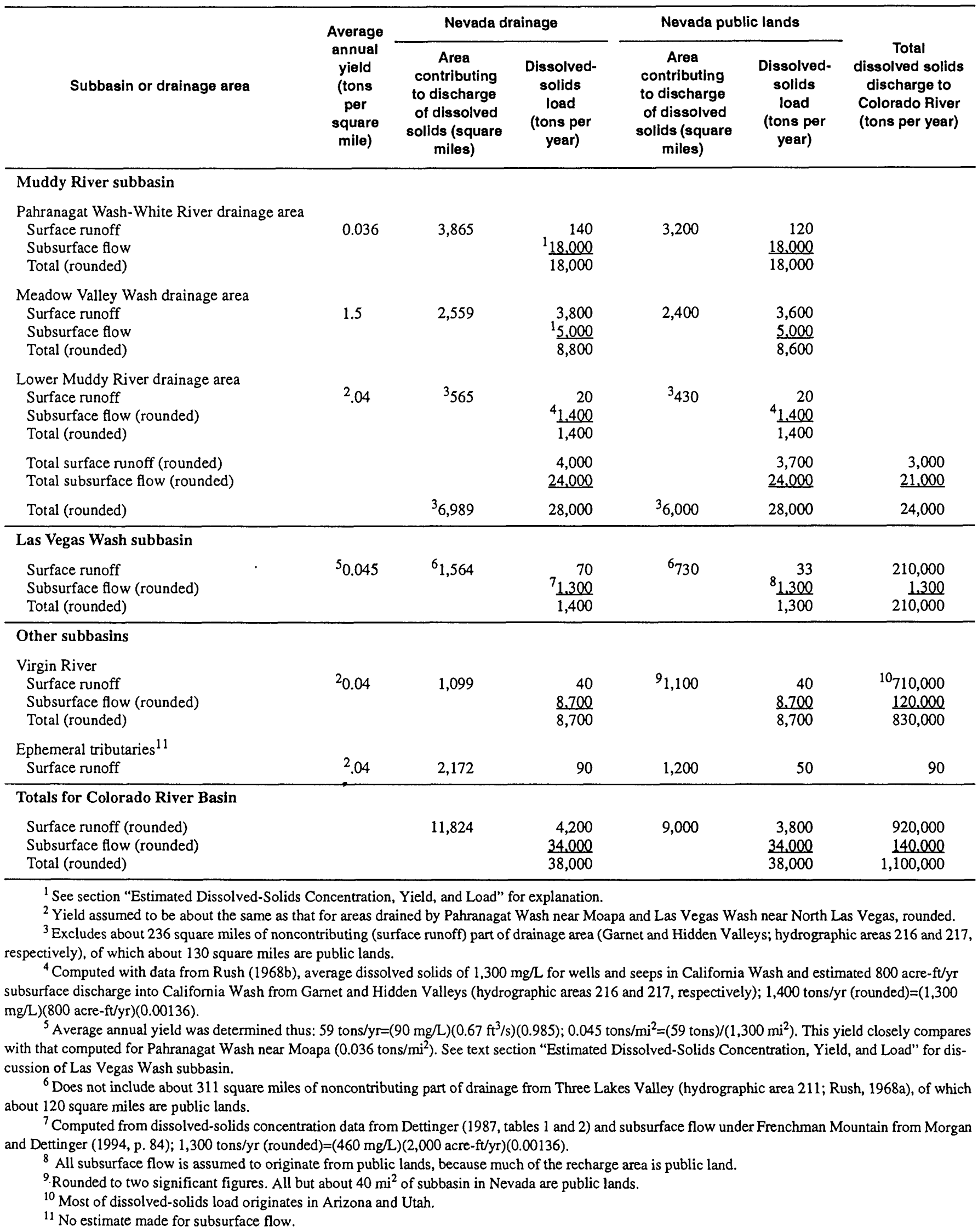


Subsurface flow of 1,100 acre-ft/yr (Rush, 1968b, p. 41) was assumed to have a dissolved-solids concentration of $2,000 \mathrm{mg} / \mathrm{L}(1,970 \mathrm{mg} / \mathrm{L}$ rounded). Thus, an additional 3,000 tons/yr of dissolved solids discharged from the Muddy River subbasin to the Colorado River by subsurface flow. Combined surface runoff and subsurface flow discharged an estimated 24,000 tons/yr (table 4 ) of dissolved solids to the Colorado River from the Muddy River subbasin.

\section{Comparison of Study-Period and Long-Term Data}

For the purposes of this report, streamflow data for water years 1977-93 for Muddy River near Moapa are considered long-term data. Some data prior to this period includes flow that is diverted upstream. Data for the period of record for Muddy River near Overton, water years 1979-93, are considered long-term data.

Streamflow for the 5-year study period (water years 1989-93) was compared with the long-term record for Muddy River near Moapa (water years 197793) and Muddy River above Lake Mead near Overton (water years 1979-93). At Muddy River near Moapa, the average annual streamflow for the study period, $37 \mathrm{ft}^{3} / \mathrm{s}$, was only 3 percent less than the long-term average annual streamflow of $38 \mathrm{ft}^{3} / \mathrm{s}$. At Muddy River above Lake Mead near Overton, the average annual streamflow for the study period, $10 \mathrm{ft}^{3} / \mathrm{s}$, was 8 percent more than the long-term average annual streamflow of $9.2 \mathrm{ft}^{3} / \mathrm{s}$.

The average annual dissolved-solids load of the Muddy River above Lake Mead near Overton was 21,000 tons/yr for both the study period, water years 1989-93, and the long-term period, water years 1979 93 (table 3). Specific conductance for Muddy River near Moapa was reported as $1,090 \mu \mathrm{S} / \mathrm{cm}$ by Eakin (1964, p. 28) and as 940 to $1,100 \mu \mathrm{S} / \mathrm{cm}$ by Bateman (1976, p. 21). These data are comparable to the average specific conductance of $1,000 \mu \mathrm{S} / \mathrm{cm}$ for $1989-93$, indicating no appreciable overall change in dissolvedsolids concentrations.

The comparisons indicate that the dissolvedsolids load for the study period is comparable to dissolved-solids load in the long term. Thus, contributions of dissolved-solids load and discharge for the Muddy River subbasin determined by this study can probably be used to represent long-term values, provided land or water use do not change significantly within the area.

\section{Las Vegas Wash Subbasin}

Streamflow in Las Vegas Wash at the North Las Vegas study site averaged $0.016 \mathrm{ft}^{3} / \mathrm{s}$ for water years $1989-93$ and 0.018 for the water years having specificconductance data (1990, 1992-93; table 2). This average is much less than the average annual streamflow of $0.67 \mathrm{ft}^{3} / \mathrm{s}$ at the now-discontinued gaging station about $6 \mathrm{mi}$ downstream for water years 1963-78 (Las Vegas Wash at North Las Vegas, sta. 09419650; U.S. Geological Survey, 1979, p. 56). The average annual streamflow at the downstream gage is thought to be a better representation of streamflow for this general reach of Las Vegas Wash.

Estimated dissolved-solids concentration in streamflow at the study site averaged $85 \mathrm{mg} / \mathrm{L}$ for water years 1990 and 1992-93 (no data for 1989 and 1991) and ranged from $61 \mathrm{mg} / \mathrm{L}$ for 1993 to $100 \mathrm{mg} / \mathrm{L}$ for 1992 (table 2). For streamflows less than $20 \mathrm{ft}^{3} / \mathrm{s}$ at the study site, specific-conductance data indicate that the dissolved-solids concentration most commonly ranges from 80 to $95 \mathrm{mg} / \mathrm{L}$ and averages about $90 \mathrm{mg} / \mathrm{L}$. For this study, the relations between streamflow and dissolved-solids concentration at the study site and at the gage about $6 \mathrm{mi}$ downstream are assumed to have been about the same during the respective periods of record. However, if instead the average dissolvedsolids concentration at the former downstream gage were twice that of the upstream site, the resultant additional load would amount to less than 10 percent of the total from public lands for this subbasin.

An average dissolved-solids load of 59 tons/yr for the Las Vegas Wash study site near North Las Vegas (table 3) was estimated using the average annual streamflow of $0.67 \mathrm{ft}^{3} / \mathrm{s}$ for the downstream gage and an average dissolved-solids concentration of $90 \mathrm{mg} / \mathrm{L}$ for the study site. An average annual yield of 0.045 ton $/ \mathrm{mi}^{2}$ was computed from the average dissolvedsolids load of 59 tons/yr, and $1,300 \mathrm{mi}^{2}$ area upstream from the lower gage. This average annual yield of $0.045 \mathrm{ton} / \mathrm{mi}^{2}$ is comparable to the average annual yield of $0.036 \mathrm{ton} / \mathrm{mi}^{2}$ estimated for the Pahranagat Wash study site.

This comparability of yields for the two drainage areas indicates that an annual yield of about 0.04 ton/ $\mathrm{mi}^{2}$ may be applicable within the study area to other drainages with ephemeral streamflow to estimate average annual dissolved-solids load. 
Surface runoff contributed an estimated 70 tons of dissolved solids annually to Las Vegas Wash, based on $0.045 \mathrm{ton} / \mathrm{mi}^{2}$ yield and $1,564 \mathrm{mi}^{2}$ subbasin area (table 4). Subsurface flow from Las Vegas Wash subbasin toward the Colorado River, beneath Frenchman Mountain on the east side of the Las Vegas Wash subbasin, was estimated as about 2,000 acre-ft/yr by Morgan and Dettinger (1994, p. 84). Although the estimate was made for predevelopment conditions in Las Vegas Valley, it is thought to be an adequate approximation for current conditions as well (James R. Harrill, U.S. Geological Survey, oral commun., 1994). Data reported by Dettinger (1987, tables 1 and 4, sites $3,19,20$, and 47 west of Frenchman Mountain) are used to determine an average dissolved-solids concentration of $460 \mathrm{mg} / \mathrm{L}$. Subsurface flow of about 2,000 acre- $\mathrm{ft} / \mathrm{yr}$ with a dissolved-solids concentration of $460 \mathrm{mg} / \mathrm{L}$ would contribute an additional 1,300 tons/yr (rounded) of dissolved solids from the Las Vegas Wash subbasin. Surface runoff and subsurface flow contributed a combined 1,400 tons/yr (rounded) of dissolved solids from the Las Vegas Wash subbasin (table 4). The subsurface flow used to calculate dissolved-solids load in this report is natural flow under Frenchman Mountain on the northeast side of the valley. Surface runoff evaluated in this report is that resulting from precipitation.

\section{Estimated Annual Dissolved-Solids Discharge to the Colorado River}

Dissolved-solids load in Las Vegas Wash near Henderson (fig. 1) averaged 210,000 tons/yr for water years 1989-92 (table 3). An estimated 1,300 tons/yr of dissolved solids moves from the Las Vegas Wash subbasin toward the Colorado River by subsurface outflow (see previous paragraph). Combined surface runoff and subsurface flow discharged about 210,000 tons/yr (rounded) of dissolved solids from the Las Vegas Wash subbasin (table 4). For comparison, an earlier study determined an average dissolved-solids load of 196,047 tons/yr for 1979-83 in Las Vegas Wash (Panian and others, 1987, p. 8).

Most of the dissolved-solids discharge in Las Vegas Wash is related to water imported from Lake Mead and native water pumped from the Las Vegas Valley ground-water system that return to the wash by way of urban landscape irrigation and treated sewage effluent. In 1991, an estimated 268,000 acre-ft of water was imported and an estimated 47,000 acre-ft was pumped (Johnson, 1992). Evaluation of the dissolvedsolids load of this water is beyond the scope of this report.

\section{Comparison of Study-Period and Long-Term Data}

For the purposes of this report, streamflow data for water years 1977-92 for Las Vegas Wash near Henderson is considered long-term data (no data available for water year 1993). This period closely corresponds to the periods used for long-term data for study sites in the Muddy River subbasin.

Streamflow for the study period (water years 1989-92) was compared with the streamflow for 1977-92. The streamflow for the study period was 150 $\mathrm{ft}^{3} / \mathrm{s}$, compared with $110 \mathrm{ft}^{3} / \mathrm{s}$ for the long-term period (table 3). The generally steady increase in streamflow in Las Vegas Wash is due to increasing water use in the Las Vegas Valley. The estimated average annual dissolved-solids load in Las Vegas Wash near Henderson was 210,000 tons/yr for water years 1989 92 and was 170,000 tons/yr for the long-term period 1977-92 (table 3). The increase in load corresponded with an increase in streamflow.

Comparison of study-period and long-term data indicates that the average annual streamflow and dissolved-solids load in lower Las Vegas Wash for the study period are not comparable to long-term conditions, because of the continued expansion of urbanized areas in Las Vegas Valley. However, average streamflow at the USGS gaging station about $6 \mathrm{mi}$ downstream from the upper study site, near North Las Vegas, probably is representative of long-term average streamflow for undeveloped areas of public lands in the Las Vegas Wash subbasin. The annual average dissolved-solids concentration of Las Vegas Wash near North Las Vegas was generally low, ranging from 61 $\mathrm{mg} / \mathrm{L}$ to about $100 \mathrm{mg} / \mathrm{L}$. This low concentration of surface runoff from public lands probably is due to the short time runoff is in contact with the soil and rocks. Average annual dissolved-solids concentration of about $90 \mathrm{mg} / \mathrm{L}$ may be a rough representation of the dissolved-solids concentration of surface runoff in undeveloped areas of the Las Vegas Valley. Characterization of the effects of urbanization in Las Vegas Valley on changes in dissolved-solids loads to Lake Mead is beyond the scope of this study and report. 


\section{Other Subbasins}

Although the Virgin River subbasin was not studied in detail, available data were used to compute rough estimates of dissolved-solids contribution. An estimated 40 tons (rounded) of dissolved solids in surface runoff may be contributed annually to the Virgin River in Nevada, on the basis of $0.04 \mathrm{ton} / \mathrm{mi}^{2}$ annual yield (see p. 20) and 1,099 $\mathrm{mi}^{2}$ subbasin area. Subsurface flow into the Lower Virgin River Valley of Nevada was estimated as 2,900 acre-ft/yr (Glancy and Van Denburgh, 1969, p. 51, 54). Water-quality data for samples from 16 wells along the Virgin River (Glancy and Van Denburgh, 1969, table 17) are used to determine an average dissolved-solids concentration of 2,200 $\mathrm{mg} / \mathrm{L}$ for subsurface flow. This concentration compares closely with the average concentration of dissolved solids in the Virgin River above Halfway Wash near Riverside $(2,000 \mathrm{mg} / \mathrm{L})$ for the period of record there (water years 1978-86). Subsurface flow of $2,900 \mathrm{acre}-\mathrm{ft} / \mathrm{yr}$ with a dissolved-solids concentration of 2,200 $\mathrm{mg} / \mathrm{L}$ contributes an estimated 8,700 tons/yr (rounded; table 4) of dissolved solids to the Nevada part of the Virgin River. Surface runoff and subsurface flow in Nevada may contribute a combined 8,700 tons/yr (rounded) of dissolved solids to the Virgin River from surface runoff and subsurface flow in Nevada.

Surface runoff in ephemeral tributaries (fig. 1) also contributes dissolved solids. A rough estimate of average dissolved-solids load of surface runoff from ephemeral tributaries is about 90 tons (rounded), on the basis of $0.04 \mathrm{ton} / \mathrm{mi}^{2}$ annual yield and $2,172 \mathrm{mi}^{2}$ area. This estimate should be used with caution because of the variety of hydrogeologic conditions in the 2,172 $\mathrm{mi}^{2}$ drained by ephemeral tributaries, which would affect the dissolved-solids yield. For example, limited water-quality data (Rush, 1968b, table 16) and geologic information suggest that surface runoff in the Black Mountains area (fig. 1) may be quite saline (A.S. Van Denburgh, U.S. Geological Survey, oral commun., 1994).

Hydrologic data are not available to estimate dissolved-solids load in subsurface flow from the ephemeral tributaries.

\section{Estimated Annual Dissolved-Solids Discharge to the Colorado River}

The dissolved-solids load in the Virgin River above Halfway Wash near Riverside, which was about 710,000 tons/yr for water years $1978-86$, may approximate the dissolved-solids load discharged to the Colorado River by streamflow. As much as 40,000 acre-ft/yr of subsurface flow may enter Lake Mead from the Virgin River subbasin (Glancy and Van Denburgh, 1969, p. 51). Assuming a dissolved-solids concentration of $2,200 \mathrm{mg} / \mathrm{L}$ for subsurface flow (see previous section), an average dissolved-solids load of 120,000 tons/yr may discharge into the Colorado River by subsurface flow. Combined surface runoff and subsurface flow may contribute about 830,000 tons/yr of dissolved solids to the Colorado River.

The average dissolved-solids load in surface runoff from ephemeral tributaries, about 90 tons/yr, is an estimate of dissolved-solids load discharged to the Colorado River. Adequate hydrologic data are not available to estimate the dissolved-solids load in subsurface flow from ephemeral tributaries discharged to the Colorado River.

\section{Comparison of Study-Period and Long-Term Data}

The annual concentration of dissolved solids in the Virgin River at Littlefield, Ariz. (fig. 1), averaged $1,900 \mathrm{mg} / \mathrm{L}$ for water years $1978-93$ and $1,800 \mathrm{mg} / \mathrm{L}$ for water years 1978-86. The average annual dissolvedsolids concentrations are based on analyses of periodic water samples. The average dissolved-solids load was about 560,000 tons/yr for water years 1978-93 (table 3 ), on the basis of about $300 \mathrm{ft}^{3} / \mathrm{s}$ average streamflow and about $1,900 \mathrm{mg} / \mathrm{L}$ average dissolved-solids concentration. For comparison, an earlier study determined an average dissolved-solids load of 541,037 tons/yr for 1979-83 in the Virgin River (Panian and others, 1987, p. 8). The average dissolved-solids load was about 640,000 tons/yr for water years $1978-86$ (table 3), on the basis of $360 \mathrm{ft}^{3} / \mathrm{s}$ average streamflow and 1,800 $\mathrm{mg} / \mathrm{L}$ average dissolved-solids concentration. Most of the dissolved-solids load in the Virgin River at Littlefield study site originates in Arizona and Utah.

The annual concentration of dissolved solids in the Virgin River above Halfway Wash near Riverside averaged $2,000 \mathrm{mg} / \mathrm{L}$ for water years $1978-86$. The dissolved-solids load averaged about 710,000 tons/yr for water years 1978-86 (table 3). Thus, the load 
increased by an average of about 70,000 tons/yr between the Littlefield and Riverside gages during water years 1978-86. This 9-year period was wetter than average: at the Littlefield gage, flow for the entire period of record (water years 1930-93) averaged 241 $\mathrm{ft}^{3} / \mathrm{s}$ (U.S. Geological Survey, 1994, p. 52), in contrast to about $360 \mathrm{ft}^{3} / \mathrm{s}$ for $1978-86$ (table 3 ).

\section{ESTIMATED ANNUAL DISSOLVED- SOLIDS YIELD AND LOAD FROM PUBLIC LANDS}

\section{Muddy River Subbasin}

Public lands constitute 86 percent of the Muddy River subbasin, as shown in table 1 . This land includes 83 percent of Pahranagat Wash-White River drainage area, 94 percent of Meadow Valley Wash drainage area, and 70 percent of the lower Muddy River drainage area. The dissolved-solid load contributed by surface runoff from public lands was computed by applying the dissolved-solids yield for the entire drainage area to the part that consists of public lands. For the lower Muddy River drainage area, the yield was applied to $430 \mathrm{mi}^{2}$, instead of $560 \mathrm{mi}^{2}$, because about $130 \mathrm{mi}^{2}$ are in hydrologic areas that do not contribute surface runoff to the Colorado River. The dissolved-solids loads contributed by public lands to the Muddy River subbasin from surface runoff in the drainage areas are 120 tons/yr from Pahranagat Wash-White River drainage area, 3,600 tons/yr from Meadow Valley Wash drainage area, and only 20 tons/yr from the lower Muddy River drainage area (table 4).

The source of subsurface flow is not identified in this report, but the general areas of recharge may be mountain slopes and channels, alluvial fans, and valley bottoms. The dissolved-solids load from subsurface flow is attributed entirely to public lands because almost 90 percent of the Muddy River subbasin is public lands. Dissolved-solids loads contributed by subsurface flow were 18,000 tons/yr from Pahranagat WashWhite River, 5,000 tons/yr from Meadow Valley Wash, and 1,400 tons/yr from the lower Muddy River drainage (table 4).
For water years 1989-93, the total contribution of dissolved solids from public lands in the Muddy River subbasin averaged about 28,000 tons/yr (rounded). Subsurface flow contributed 24,000 tons/yr of dissolved solids. The annual dissolved-solids yield for public lands in the Muddy River subbasin was about 4.5 tons $/ \mathrm{mi}^{2}$ [determined from $(28,000$ tons/yr $) /(6,200$ $\left.\mathrm{mi}^{2}\right)$ ] for the same period.

\section{Las Vegas Wash Subbasin}

Public lands are 45 percent of the Las Vegas Wash subbasin, as shown in table 1 . The dissolved-solids load contributed by surface runoff from public lands was computed by applying the annual dissolved-solids yield of $0.045 \mathrm{ton} / \mathrm{mi}^{2}$ to the area of public lands within the drainage area. Approximately $730 \mathrm{mi}^{2}$ of public lands contribute dissolved solids in the Las Vegas Wash subbasin. An additional $120 \mathrm{mi}^{2}$ of public lands are in a hydrographic area, Three Lakes Valley (hydrographic area 211), that is a noncontributing part of the Colorado River Basin. The total average dissolved-solids load contributed by surface runoff from public lands was 33 tons/yr.

The source of subsurface flow from public lands is the ground-water system of the Las Vegas Valley. Recharge to the ground-water system is from precipitation in the Spring Mountains that border the west side of the valley and in the Sheep Range that borders the north side of the valley (Harrill, 1976, p. 2). Dissolved-solids load from subsurface flow is attributed entirely to public land because much of the recharge area and the flow path downgradient therefrom underlie public land. Dissolved-solids load contributed to the Las Vegas Wash subbasin from subsurface flow in the drainage area was approximately 1,300 tons/yr. The combined total from surface runoff and subsurface flow is about 1,300 tons/yr (rounded). The annual dissolved-solids yield for public lands in the Las Vegas Wash subbasin was almost 2 tons $/ \mathrm{mi}^{2}$ [determined from $\left(1,300\right.$ tons/yr) / $\left(730 \mathrm{mi}^{2}\right)$ ].

\section{Other Subbasins}

All but about $40 \mathrm{mi}^{2}$ of the Virgin River subbasin within Nevada consists of public lands. Surface runoff from public lands in the Virgin River subbasin may contribute an estimated 40 tons/yr of dissolved solids, 
on the basis of $0.04 \mathrm{ton} / \mathrm{mi}^{2}$ annual yield and about $1,100 \mathrm{mi}^{2}$ of public lands. Dissolved-solids load from subsurface flow in Nevada is attributed entirely to public land. Subsurface flow from public lands may contribute an estimated 8,700 tons/yr of dissolved solids. Combined dissolved-solids load from public lands is about 8,700 tons/yr (rounded) and annual dissolvedsolids yield for public lands is about 7.9 tons $/ \mathrm{mi}^{2}$ [determined from $\left(8,700\right.$ tons/yr) $/\left(1,100 \mathrm{mi}^{2}\right)$ ].

A rough estimate of average dissolved-solids load in surface runoff from public lands in ephemeral tributaries is 50 tons/yr [determined from $(0.04$ ton/yr) $\left.\left(1,200 \mathrm{mi}^{2}\right)\right]$. No estimate was made for dissolved-solids load in subsurface flow from these lands.

\section{IMPLICATION OF FINDINGS FOR MANAGEMENT OF DISSOLVED-SOLIDS DISCHARGE FROM PUBLIC LANDS}

Subsurface flow contributes about 87 percent of the dissolved-solids load from public lands in the Muddy River and Las Vegas Wash subbasins, whereas surface runoff contributes the remaining 13 percent of the load. Although about 7,000 $\mathrm{mi}^{2}$ of the two subbasins are public lands, the arid climate of the study area and low annual runoff limit the contributions of dissolved solids from surface runoff. The low concentration of dissolved solids normally associated with surface runoff also limits the contribution.

Surface runoff and subsurface flow from public lands in the Nevada part of the Colorado River Basin contribute an estimated average total of 38,000 tons/yr (rounded) - 28,000 tons/yr in the Muddy River subbasin, 1,300 tons/yr in Las Vegas Wash subbasin, 8,700 tons/yr in the Virgin River subbasin, and 50 tons/yr in areas drained by ephemeral tributaries. Hydrologic conditions that are unique to the subbasins are discussed in the following sections.

\section{Muddy River Subbasin}

The BLM manages about $6,200 \mathrm{mi}^{2}$ of land in the Muddy River subbasin of Nevada (table 1). The Muddy River flows into Lake Mead (an impoundment of the Colorado River) and discharges dissolved solids into the lake. Contributions of dissolved-solids load from the public lands were estimated from data collected at study sites within the subbasin and data compiled from other sources. About 28,000 tons/yr of dissolved solids were contributed by surface runoff and subsurface flow from public land during water years 1989-93.

An estimated 86 percent of the dissolved-solids load $(24,000$ tons/yr) was contributed by subsurface flow from public lands (table 4). The percentage actually may be somewhat higher, because streamflow at the Meadow Valley Wash study site was assumed to be surface runoff, although discharge from a spring upstream provided most of the total annual flow.

Because surface runoff contributes less than 15 percent of the total dissolved-solids load from public lands, management practices in these lands probably would not substantially reduce the overall load.

Hydrologic data collected at the Meadow Valley Wash study site show occasional spikes of specific conductance to a recorded maximum of $7,460 \mu \mathrm{S} / \mathrm{cm}$ (U.S. Geological Survey, 1994, p. 70). Perhaps related to the periodic conductance spikes is the tendency-at flows less than $5 \mathrm{ft}^{3} / \mathrm{s}$-for dissolved-solids concentration to increase with increased flow (in most streams, dissolved-solids concentration is inversely proportional to flow, owing to dilution). This unusual hydrologic phenomenon may be due at least in part to local input of salts directly and indirectly related to dense stands of riparian saltcedar upstream from the Meadow Valley Wash study site (Hem, 1967, p. 6).

A 1975 study by Desert Research Institute (DRI) for BLM (Bateman, 1976) included the Muddy River and Virgin River subbasins. Bateman collected or compiled data on dissolved-solids concentrations at 169 sites including wells, springs, streams, and irrigation return flow. Future investigations, using detailed data for the Meadow Valley Wash study site (present study) and the DRI study, may identify specific sources of discharge or land areas that could be managed for reduction of dissolved-solids load. Any such reduction may not substantially affect the overall dissolved-solids contribution to the Muddy River subbasin, however, because the contribution from an individual specific source would be relatively minor compared to the total basin load.

Agricultural land use downstream from public lands may potentially affect dissolved-solids discharge to the Colorado River. About 4,900 acres of crops and pasture lands are irrigated in lower Meadow Valley Wash, upper Moapa Valley, and lower Moapa Valley (U.S. Soil Conservation Service, 1993, p. ii). Water is diverted from the Muddy River for irrigation. Average annual streamflow of $38 \mathrm{ft}^{3} / \mathrm{s}$ near Moapa is reduced to 
about $10 \mathrm{ft}^{3} / \mathrm{s}$ above Lake Mead near Overton. Part of the reduction is due to evapotranspiration along the stream, but a large part of the loss is due to diversion of water for irrigation and subsequent evapotranspiration losses from crops and pastures and evaporation losses from irrigation ditches and reservoirs. Accumulation of the dissolved solids in the agriculture areas may partly reduce the total contribution of 28,000 tons/yr of dissolved solids from the upstream parts of the Muddy River subbasin to 24,000 tons/yr of discharge to the Colorado River. The apparent loss of 4,000 tons/yr of dissolved solids in the Lower Muddy River subbasin also may be due at least in part to the limited accuracy of the method used to estimate dissolved-solids contributions. More detailed studies of water chemistry in the lower Muddy River subbasin may provide additional information for evaluating changes in dissolved-solids concentration and load.

The U.S. Soil Conservation Service (USSCS) studied the lower Muddy River subbasin to determine dissolved-solids load in the lower Muddy River subbasin and discharge to Lake Mead (U.S. Soil Conservation Service, 1993). The surface-runoff component of dissolved-solids discharge as determined by the USSCS study (p. 26) was 14,300 tons/yr on the basis of average streamflow of $8.42 \mathrm{ft}^{3} / \mathrm{s}$ and average dissolvedsolids concentration of $1,735 \mathrm{mg} / \mathrm{L}$. The present (1994) study determined 21,000 tons/yr on the basis of average streamflow of $9.2 \mathrm{ft}^{3} / \mathrm{s}$ and dissolved-solids concentration of $2,300 \mathrm{mg} / \mathrm{L}$. However, the USSCS reports a discharge of 42,200 tons/yr of dissolved solids due to subsurface flow (U.S. Soil Conservation Service, 1993, p. 26). In contrast, this present study determined a discharge of only 3,000 tons/yr (table 4) of dissolved solids from subsurface flow. Differing estimates of subsurface flow and dissolved-solids concentrations resulted in large differences in estimates of dissolvedsolids loads. More detailed estimates of subsurface flow and dissolved-solids concentrations are needed to resolve these differences.

\section{Las Vegas Wash Subbasin}

Factors that may affect the runoff from public lands in the Las Vegas Wash subbasin are the flooddetention basins on major channels draining public lands and the large urban area between most of the public lands and the mouth of Las Vegas Wash. Large streamflows in Las Vegas Wash during rainfall consist mostly of runoff from the urban area. Most public lands in the Las Vegas Wash subbasin that are transferred to private ownership are subsequently developed, thus, adding to the total urban area; this urbanization could increase the dissolved-solids load. An evaluation of the effects of urbanization in Las Vegas Valley on dissolved-solids loads to Las Vegas Wash is beyond the scope of the current study.

The relatively small amount of subsurface flow from the Las Vegas Wash subbasin (Harrill, 1976, p. 2) limits the contribution of dissolved solids from public lands to the Colorado River. Prior to development, almost all the recharge from natural sources in the subbasin (25,000 acre-ft; Malmberg, 1961, p. 17), was lost because of evapotranspiration and spring discharge.

Land-management practices, implemented to reduce the contribution of dissolved solids from public lands, probably would not substantially reduce the dissolved-solids discharge to the Colorado River, considering the small amount of natural subsurface flow to the Colorado River and the extensive development of the ground-water system, the presence of flood-detention basins, and the continued expansion of the large urban area in the subbasin.

The average discharge of dissolved solids to the Colorado River from Las Vegas Wash was about 210,000 tons/yr for 1989-92. The average dissolvedsolids concentration of discharge from Las Vegas Wash (about $1,400 \mathrm{mg} / \mathrm{L}$ ) was higher than the concentration in public-supply water imported from Lake Mead (about $600-800 \mathrm{mg} / \mathrm{L}$ ) or pumped from native ground water (about $300 \mathrm{mg} /$; Jeffrey A. Johnson, Las Vegas Valley Water District, and Ray J. Hoffman, U.S. Geological Survey, written communs., 1994). As the population of the valley increases, the dissolved-solids load of the Wash is expected to increase.

\section{Other Subbasins}

Combined surface runoff and subsurface flow in the Virgin River subbasin may discharge about 830,000 tons/yr of dissolved solids to the Colorado River (table 4). The dissolved-solids load increased by an average of about 70,000 tons/yr between the Littlefield and Riverside gages during the wetter-than-average period of concurrent record (water years 1978-86; see table 3). Dissolved-solids contributions from surface runoff due to precipitation and from subsurface flow within Nevada, calculated as about 8,700 tons/yr (table 4), account for only about 12 percent of this increase. 
Efforts to reduce dissolved-solids contribution from public lands in the Nevada part of the Virgin River subbasin probably would not substantially affect the dissolved-solids discharge to the Colorado River.

The public land area drained by ephemeral tributaries $\left(1,200 \mathrm{mi}^{2}\right)$ is widespread with numerous individual channels tributary to the river, Lake Mead, or Lake Mohave. The average annual yield for the public lands is assumed to be $0.04 \mathrm{ton} / \mathrm{mi}^{2}$. Because of the low yield and numerous individual tributaries, landmanagement practices in these areas probably would not substantially reduce the contribution of dissolved solids from the public lands drained by ephemeral tributaries.

\section{SUMMARY}

About 9,300 of the $12,400 \mathrm{mi}^{2}$ (75 percent) of Colorado River Basin in Nevada are administered by the Bureau of Land Management. The administered tracts are referred to as public lands and are subject to Public Law 98-569, which directs the Secretary of the Interior to develop a comprehensive program for minimizing dissolved-solids contributions to the Colorado River from public lands. About $6,200 \mathrm{mi}^{2}$ of public lands are in the Muddy River subbasin and about $850 \mathrm{mi}^{2}$ are in the Las Vegas Wash subbasin. Data available prior to 1988 for the two subbasins were generally for locations downstream from all potential sources of dissolved solids and were insufficient to estimate dissolved-solids contributions from public lands only.

Four study sites were established in calendar year 1988 , in cooperation with the Bureau of Land Management, to assess the dissolved-solids loads from public lands in the Nevada part of the Colorado River Basin. The study sites were on Pahranagat Wash, Muddy River, Meadow Valley Wash, and Las Vegas Wash. Water samples were collected during site visits and analyzed for specific conductance and for dissolved-solids concentration. Additional water samples were collected during periods of storm runoff. Streamflow and specific-conductance data were recorded half-hourly at Pahranagat Wash near Moapa and Las Vegas Wash near North Las Vegas and hourly at Muddy River near Moapa and Meadow Valley Wash near Rox. Data were collected at the study sites through September 1993. These data and additional information compiled for other sites were used to estimate the dissolved-solids contributions from Nevada public lands.

The average dissolved-solids discharge from the Muddy River subbasin to the Colorado River, from October 1988 to September 1993, was about 24,000 tons/yr, including that from subsurface flow. The estimated average dissolved-solids load that was contributed from Nevada public lands in the Muddy River subbasin was 28,000 tons/yr for the same period, of which subsurface flow contributed about 86 percent (24,000 tons/yr). The difference of 4,000 tons/yr may be partially due to salt losses in agriculture areas in the lower parts of the basin, inaccuracies in the methods used to estimate dissolved-solids load, or both.

The average dissolved-solids discharge from the Las Vegas Wash subbasin to the Colorado River, from October 1988 to June 1992, was about 210,000 tons/yr, including that from subsurface flow. The estimated average dissolved-solids load contributed from public lands in the Las Vegas Wash subbasin was 1,300 tons/yr for October 1988 through September 1993.

Available data were compiled to estimate dissolved-solids loads in the Virgin River subbasin. All but about $40 \mathrm{mi}^{2}$ of the subbasin within Nevada is public lands. An estimated 40 tons/yr of dissolved solids may be contributed to the Virgin River by surface runoff from those lands. About 8,700 tons/yr of dissolved solids may be contributed to the Virgin River by subsurface flow from public lands. Thus, the combined dissolved-solids load from public lands is about 8,700 tons/yr (rounded).

The average dissolved-solids load in surface runoff from Nevada public lands in ephemeral tributaries to the Colorado River and its impoundments is estimated as 50 tons/yr. Available information was insufficient to permit an estimate of dissolved-solids load in subsurface flow from those lands.

In summary, a total of about 38,000 tons (rounded) of dissolved solids is contributed annually to the Colorado River Basin by surface runoff and subsurface flow from public lands in Nevada. Land-management practices probably would not substantially reduce this contribution. 


\section{REFERENCES CITED}

Bateman, R.L., 1976, Inventory and chemical quality of ground water in the White River-Muddy RiverMeadow Valley Wash area, southeastern Nevada: University of Nevada, Desert Research Institute Project Report 40, 44 p.

Dettinger, M.D., 1987, Ground-water quality and geochemistry of Las Vegas Valley, Clark County, Nevada, 198183-Implementation of a monitoring network: U.S. Geological Survey Water-Resources Investigations Report 87-4007, 69 p.

Eakin, T.E., 1964, Ground-water appraisal of Coyote Spring and Kane Spring Valleys and Muddy River Springs area, Lincoln and Clark Counties, Nevada: Nevada Department of Conservation and Natural Resources, Ground-Water Resources - Reconnaissance Report 25, $40 \mathrm{p}$.

Glancy, P.A., and Van Denburgh, A.S., 1969, Waterresources appraisal of the lower Virgin River Valley area, Nevada, Arizona, and Utah: Nevada Division of Water Resources, Reconnaissance Report 51, 87 p.

Gortsema, G.C., 1993, Selected data on water quantity and quality at four sites on streams draining public lands, Colorado River Basin, southeastern Nevada, October 1988 - September 1991: U.S. Geological Survey OpenFile Report 93-439, 31 p.

Harrill, J.R., 1976, Pumping and ground-water storage depletion in Las Vegas Valley, Nevada, 1955-74: Nevada Division of Water Resources, Bulletin 44, 70 p.

Hem, J.D., 1967, Composition of residues on leaves and stems of saltcedar (Tamarix pentandra Pallas): U.S. Geological Survey Professional Paper 491-C, 9 p.

- 1985, Study and interpretation of the chemical characteristics of natural water [3d ed.]: U.S. Geological Survey Water Supply Paper 2254, 283 p.

Johnson, Michael, 1992, Ground-water conditions in the Las Vegas Valley: Association of Engineering Geologists, Southwestern Section, Geologic and Hydrologic Hazards in the Las Vegas Valley-A One-Day Workshop, Las Vegas, December 1992, unpaginated.

Malmberg, G.T., 1961, A summary of the hydrology of the Las Vegas ground-water basin, Nevada, with special reference to the available supply: Nevada Department of Conservation and Natural Resources, Water Resources Bulletin 18, 23 p.

Morgan, D.S., and Dettinger, M.D., 1994, Ground-water conditions in Las Vegas Valley, Clark County, Nevada. Part II, Geohydrology and simulation of ground-water flow: U.S. Geological Survey Open-File Report 90$179,151 \mathrm{p}$.
Panian, T., Miller, W.W., and Gifford, G.F., 1987, Salinity contribution to Colorado River from Nevada basin components: Reno, Nev., Bureau of Land Management Report BLMNVPT87077200, 33 p.

Rush, F.E., 1968a, Index of hydrographic areas in Nevada: Nevada Division of Water Resources, Information Report 6, 38 p.

_ 1968b, Water-resources appraisal of the Lower MoapaLake Mead area, Clark County, Nevada: Nevada Division of Water Resources, Reconnaissance Report $50,66 \mathrm{p}$.

Thomas, J.M., and Welch, A.H., (in press), Geochemistry and isotope hydrology of representative aquifers in the Great Basin region of Nevada, Utah, and adjacent states: U.S. Geological Survey Professional Paper 1409-C.

U.S. Department of the Interior, 1991, Quality of water, Colorado River Basin: Bureau of Reclamation, Progress Report 15, 103 p.

U.S. Geological Survey, 1978-94, Water resources data, Nevada, water years 1977-93: U.S. Geological Survey Water-Data Reports NV-77-1 to NV-93-1 (published annually).

U.S. Soil Conservation Service, 1993, Salinity control plan and final environmental impact statement, Moapa Valley unit, Colorado River Basin Salinity Control Program, Clark County, Nevada: Reno, Nev., 185 p. 